\title{
Evaluation of High-Efficiency Gas-Liquid Contactors For Natural Gas Processing
}

Semi-Annual Report

April - September 1995

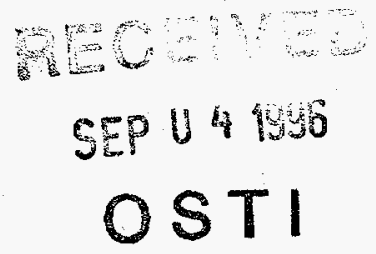

November 1995

Work Performed Under Contract No.: DE-FC21-92MC28178

For

U.S. Department of Energy

Office of Fossil Energy

Morgantown Energy Technology Center

Morgantown, West Virginia

By

Institute of Gas Technology

1700 S. Mt. Prospect Road

Des Plaines, IL 60018

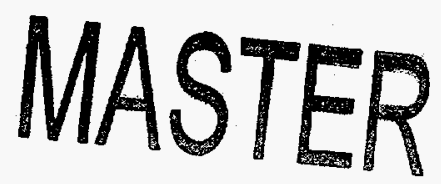




\section{DISCLAIMER}

Portions of this document may be illegible in electronic image products. Images are produced from the best available original document. 


\section{DISCLAIMER}

This report was prepared as an account of work sponsored by an agency of the United States Government. Neither the United States Government nor any agency thereof, nor any of their employees, makes any warranty, express or implied, or assumes any legal liability or responsibility for the accuracy, completeness, or usefulness of any information, apparatus, product, or process disclosed, or represents that its use would not infringe privately owned rights. Reference herein to any specific commercial product, process, or service by trade name, trademark, manufacturer, or otherwise does not necessarily constitute or imply its endorsement, recommendation, or favoring by the United States Government or any agency thereof. The views and opinions of authors expressed herein do not necessarily state or reflect those of the United States Government or any agency thereof.

Available to the public from the National Technical Information Service, U.S. Department of Commerce, 5285 Port Royal Road, Springfield, VA 22161; phone orders accepted at (703) 487-4650.

This report has been reproduced directly from the best available copy. 


\title{
Evaluation of High-Efficiency Gas-Liquid Contactors For Natural Gas Processing
}

\author{
Semi-Annual Report \\ April - September 1995
}

Work Performed Under Contract No.: DE-FC21-92MC28178

\author{
For \\ U.S. Department of Energy \\ Office of Fossil Energy \\ Morgantown Energy Technology Center \\ P.O. Box 880 \\ Morgantown, West Virginia 26507-0880
}

By

Institute of Gas Technology

1700 S. Mt. Prospect Road

Des Plaines, IL 60018

November 1995 
Technical Progress Report (6th Semi-Annual)

Cooperative Agreement No. DE-FC21-92MC28178

Reporting Period: 04/01/95 - 09/30/95

\section{PROJECT OBJECTIVE}

The objective of this proposed program is to ensure reliable supply of high-quality natural gas by reducing the cost of treating subquality natural gas containing $\mathrm{H}_{2} \mathrm{O}, \mathrm{CO}_{2}, \mathrm{H}_{2} \mathrm{~S}$ and/or trace quantities of other gaseous impurities by applying high-efficiency rotating and structured packing gas liquid contactors.

\section{WORK TO BE PERFORMED THIS REPORTING PERIOD}

- Continue viscosity studies on low pressure rotary contactor system.

- Select first host site for field testing using structured packing amine skid.

- Visit and assess the suitability of MichCon's Vienna facility for field tests.

- Complete simulations on Shell's Fandango facility.

- Prepare the trailer unit for field testing.

- Make a presentation to Shell regarding Fandango Plant simulation results.

- Complete the construction of skid-mounted amine plant.

- Prepare the trailer unit for field testing.

WORK ACCOMPLISHED DURING THE MONTH

Task 1. National Environmental Policy Act

This task was completed.

\section{Task 2. Field Experimental Site Selection}

A meeting was convened at Shell Oil Company headquarters on April 5, 1995 at Houston to discuss the modalities of field testing at one or more of Shell plant sites using structured packing $10 \mathrm{gpm}$ skid mounted amine unit. Shell requested IGT to conduct simulations on their Fandango facility using Aspen Plus simulator prior to their approval to 
conduct field tests. Accordingly, IGT conducted a detailed simulation incorporating the existing plant operating conditions at Fandango facility. A presentation was made to Shell Oil Company on September 14, 95 summarizing the simulation results. Based on the simulation results, Shell Oil Company has agreed to provide the site and utilities required for conducting the fields at Fandango plant using 10-gpm field test unit. Site preparation is under progress. A suitable place has been identified to install the skid unit on a concrete pad at Fandango plant location. All the required tie-ins have been identified between the Fandango's main plant and IGT's pilot plant. A pre-installation meeting has been scheduled between IGT and Fandango Plant personnel on October 26, 95 to discuss the pilot plant operation and safety features of the pilot plant. This meeting is part of Hazop and OSHA requirement. The information required for NEPA is under preparation for all the three sites. The trailer unit housing the analytical equipment is ready for shipping and will be shipped to site along with field test unit.

During IGT's Sustaining Membership Program meeting, we had an opportunity to discuss with Mr. Steve Kurmas, Director of Engineering of MICHCON plants for possible second location for field testing at one of their six plants located in Northern Michigan. MICHICON is very much interested in providing site for field testing. MichCon has agreed to provide field test site at their Vienna location. A meeting was conducted on August 17th and 18th at Detroit to discuss the extent of MichCon's involvement in the research program and modalities of field testing. A trip was also made to Vienna facility which is located about 220 miles north of Detroit. MICHCON agreed to provide the site and the following services as in-kind funding to the project.

- concrete slab (20'x20') for installing the skid unit

- manpower for unloading and installing the skid unit

- slip stream of sour gas upto 1 MMSCFD

- all the necessary tie-ins

- electric power (40 KVA)

- instrument air and process water make available an engineer/technician as when needed 


\section{Task 3. Field Experimental Skid Unit Design And Preliminary Economic Evaluations}

A 10-gpm structured packing skid-mounted amine unit was designed and subcontracted to GasTech Engineering for fabrication. As of end September' 95, the construction of the field test is almost complete except for insulation. The following are the observations made during the various trips made to GasTech Engineering on the progress made on the construction of 10gpm structured packing amine plant

- All the steel work has been completed.

- All the piping work has been completed.

- All the vessels have been pressure tested according to ASME code.

- All the instrumentation required for the skid unit such as RTD's, flow controllers, pressure gauges, liquid level controllers, solenoids have been installed.

- Safety features such as Emergency Shut Down (ESD) system, $\mathrm{H}_{2} \mathrm{~S}$ and combustible alarms, safety showers and eye wash stations have been provided.

- Ladders with steel cages have been provided on two sides of the skid unit.

- The skid unit has been painted.

- Most of the electrical work has been completed. It may take another week to complete the entire electrical work.

- Some of the liquid lines need to be heat traced and insulated. This work is not yet started and may take a week or two to complete it.

- After completion of the electrical work, the unit will be powered and all the instruments will be tested using computer and GE Fanuc PLC software.

Preparation of Trailer unit at IGT is under progress. The trailer unit will be shipped to test site along with the skid unit. All the analytical equipment such as GC's, alarm controls and central computer system will be stationed in this trailer. All the analytical work such as feed gas and residue gas analysis will be done at site using the instruments in the trailer. Two GC's are already installed in the trailer and we are in the process of acquiring another GC which has capability of identifying low concentrations of $\mathrm{H}_{2} \mathrm{~S}$ in ppm level. Another meeting was held at GasTech Engineering on April 28, 1995 to review the progress made on the construction of structured packing amine unit. The details are as follows: 
1. Fabrication of all vessels has been completed except the surge tank. The fabricated vessels have been $\mathrm{X}$-rayed and duly certified according to ASME code for pressure vessels.

2. Two rich/lean exchangers have been received.

3. All the required instrumentation has been received.

4. Computer along with data acquisition system has been received and tested at GasTech facilities using GE fanuc software.

5. The structural fabrication all floors on skid unit are almost complete.

6. Due to the changes suggested by Shell Oil Company to meet their own safety standards, additional work is required on skid unit such as providing ESD (electronic shut down in case of emergency), providing the lighting on each floor, providing stairs with cage, and providing eye wash stations and shower. All these modifications were incorporated in its design.

7. Due to the additional work, the delivery date for skid unit has been postponed to June' 95 .

Photographs pertaining to the trailer unit and skid-mounted amine unit are shown in Figure's 1 to 4 .

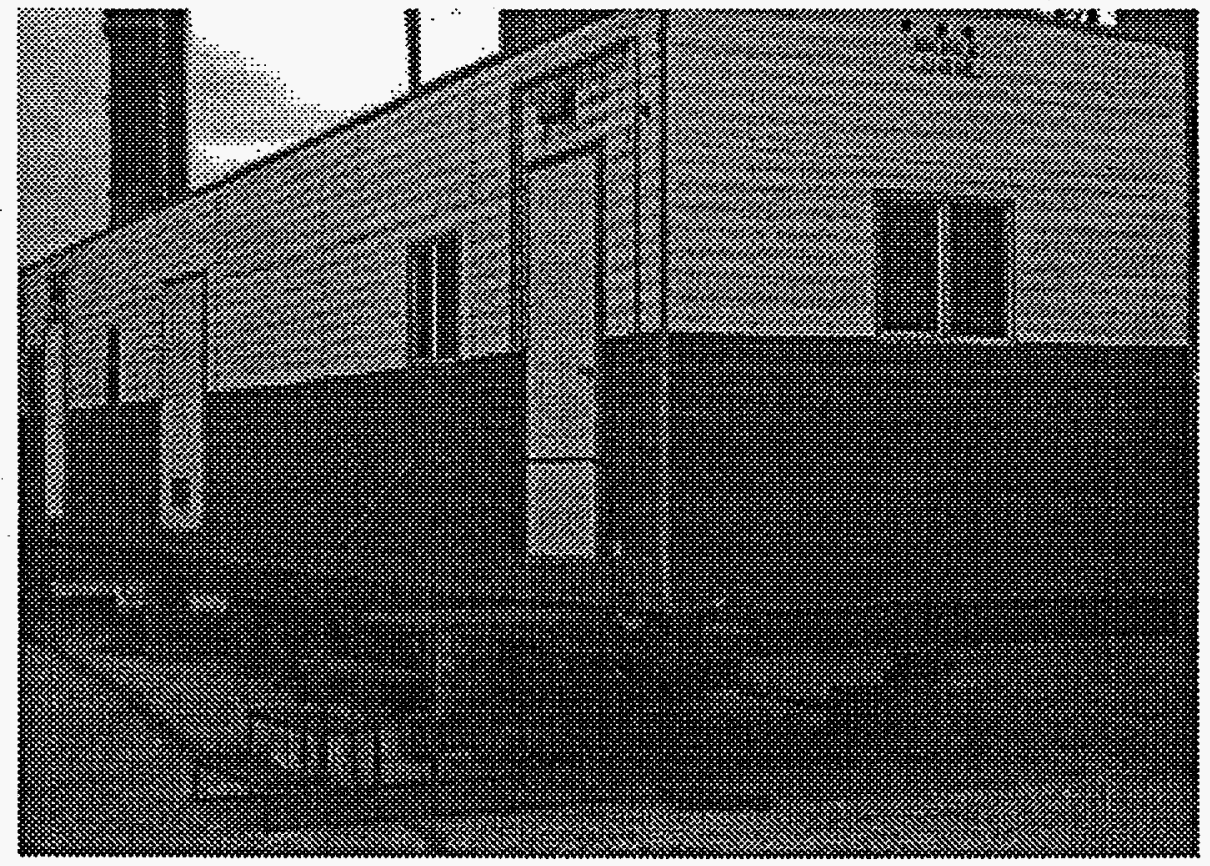

Figure 1. Elevation of the trailer unit 


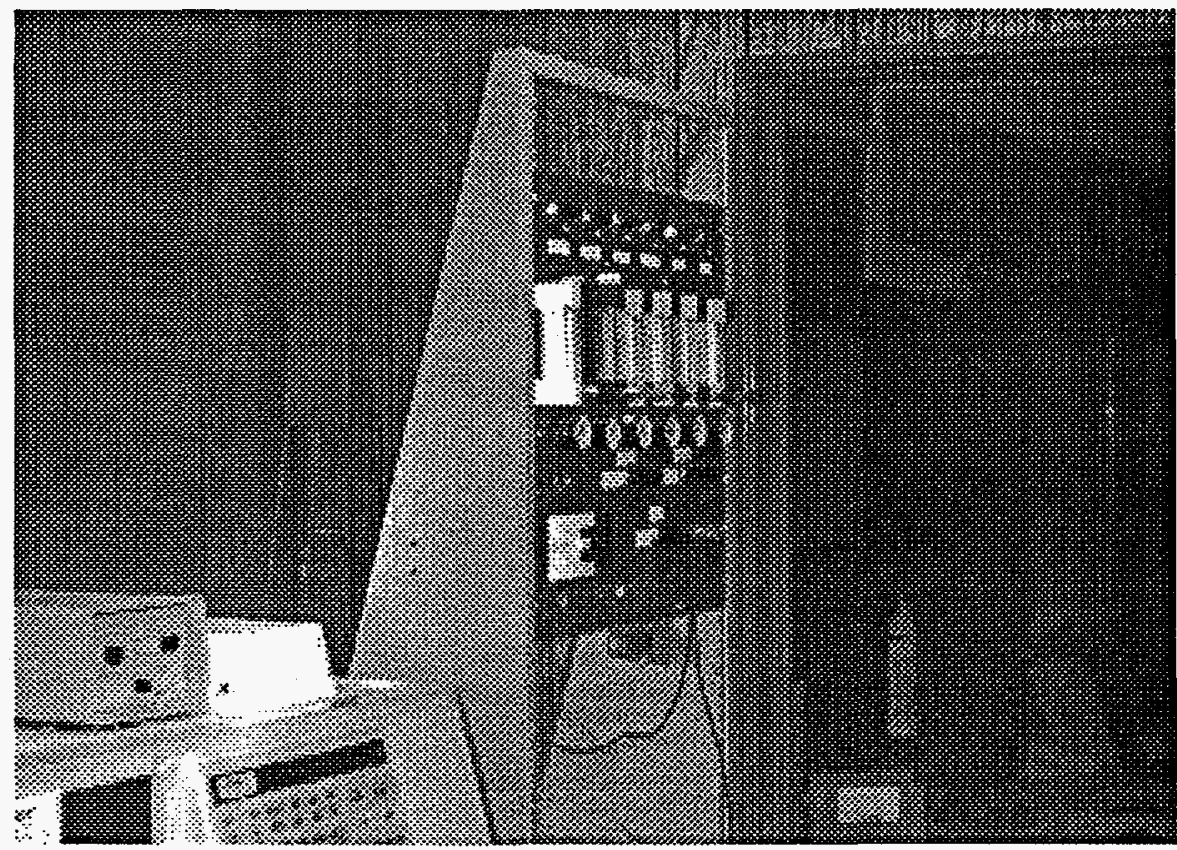

Figure 2. On-line sampling system and GC in the trailer unit

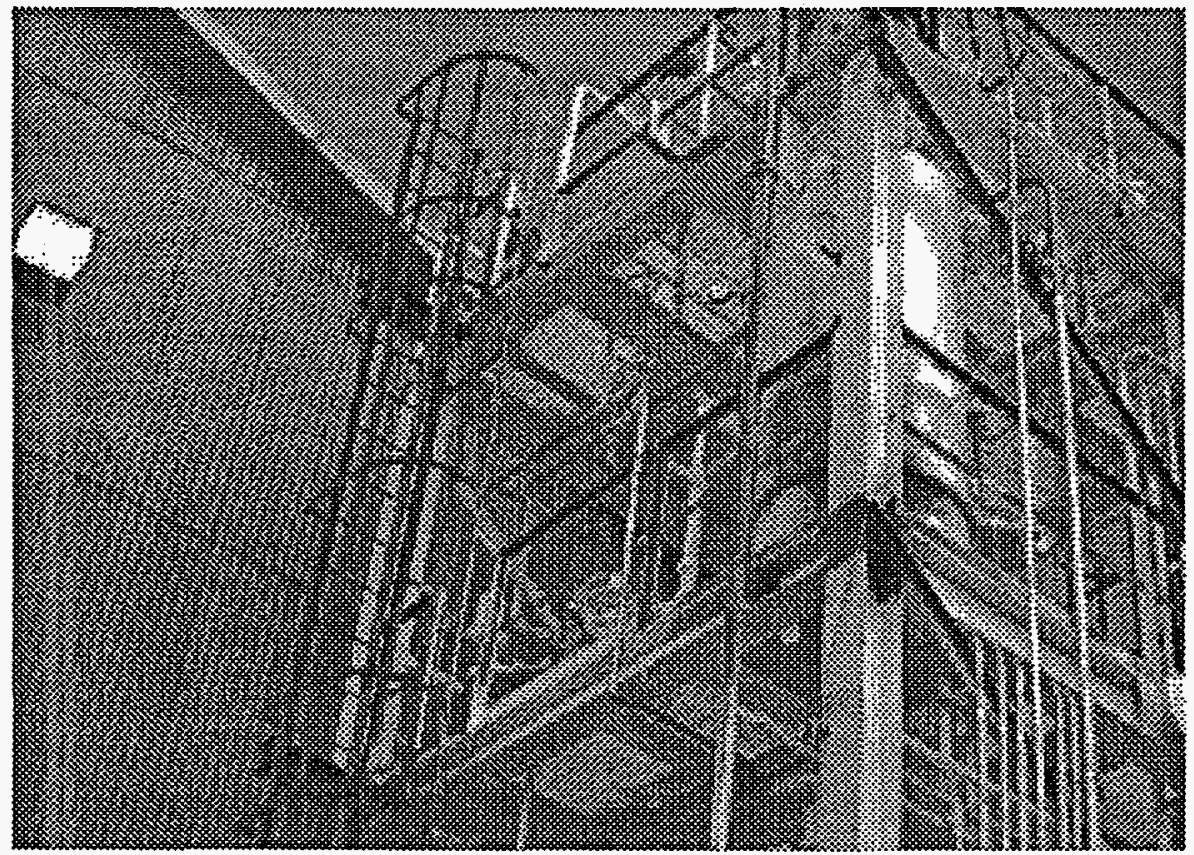

Figure 3. Isometric view of the skid-unit showing third and fourth floors 


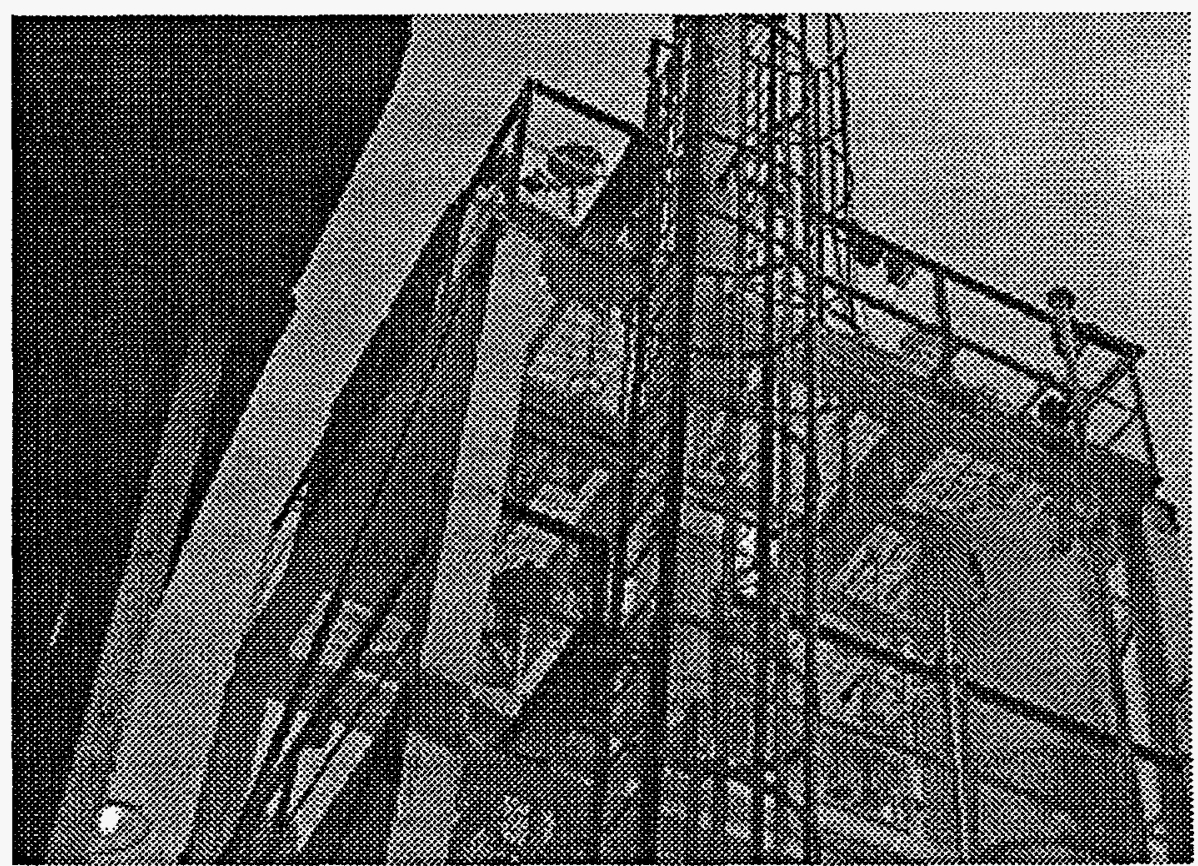

Figure 4. Isometric view of the skid unit showing contactor and regenerator

The construction of 10-gpm structured packing amine plant is complete. The unit was powered and tested using GE Fanuc PLC's and ready for shipping. GasTech also obtained quotations for shipping the unit either to Fandango or Vienna site. The unit will be shipped to the Fandango site after final inspection of the unit by GasTech. The trailer which is at IGT with all the analytical equipment is also ready and will be shipped to site along with pilot plant in November'95.

\section{Task 4. Project Review}

This task was inactive.

\section{Task 5. Information Required for NEPA, Field Site}

This information required for NEPA for all the three sites is under preparation and shall be submitted to DOE shortly. 


\section{Task 6. Fluid Dynamic Studies}

A total of twenty experimental runs were made at viscosity's $2.8 \mathrm{cp}, 5.6 \mathrm{cp}$ and $8.5 \mathrm{cp}$ to verify the effect's solution viscosity on residence time in rotary contactor. The results are summarized in the following table 1.

TABLE 1 . RESIDENCE TIME DATA AT VARIOUS VISCOSITIES

\begin{tabular}{|l|l|l|l|l|l|}
\hline $\begin{array}{l}\text { Rotor Speed } \\
\text { rpm }\end{array}$ & $\begin{array}{l}\text { Liquid Flow } \\
\text { Rate, gpm }\end{array}$ & $\begin{array}{l}\text { Residence } \\
\text { Time at lcp }\end{array}$ & \multicolumn{3}{|c|}{ Residence Time at Viscosity } \\
$2.8 c p$ & \multicolumn{3}{|c|}{$5.6 \mathrm{cp}$} & \multicolumn{1}{|c|}{$8 \mathrm{cp}$} \\
\hline 600 & 45 & & 6.86 & & \\
\hline 600 & 60 & 5.01 & 5.48 & 6.17 & \\
\hline 750 & 45 & 5.15 & 5.88 & & \\
\hline 750 & 60 & 4.58 & 4.72 & 4.88 & \\
\hline 750 & 75 & 4.11 & 3.78 & & \\
\hline 900 & 45 & 5.28 & 4.86 & 5.96 & \\
\hline 900 & 60 & 4.31 & 4.33 & 5.14 & 5.33 \\
\hline 900 & 75 & & 2.99 & & \\
\hline 1200 & 30 & 6.23 & & 7.21 & 7.79 \\
\hline 1200 & 60 & 3.74 & 3.80 & & \\
\hline 1200 & 75 & 2.93 & 3.28 & & \\
\hline
\end{tabular}

Preliminary analyses of the above results thus far indicate that the higher the viscosity, the higher the residence time in the rotary contactor which in turn results in higher hold-up volume.

Additional runs are planned for the month of May at higher viscosity's in the range of 8-15 cp. More detailed analysis of above viscosity runs will be reported in next monthly report. The tracer response curves of above runs are given in Appendix $A$ of this report. 
As of date, we have completed all the scheduled viscosity runs in the viscosity range upto 8.5 centipoise. An attempt was also made to run experiments at a higher viscosity in the range of 12$15 \mathrm{cp}$. In spite of best efforts, we couldn't get good data i.e., cleaner electrode tracer response curves, at $12 \mathrm{cp}$ viscosity and higher due to the following reasons.

As already mentioned in our previous monthly reports, an additive Polyox ${ }^{\mathrm{TM}}$ was used to alter the solution viscosity, surface tension and also to minimize the solution foaming, a defoamer was added. Due to the addition of large quantities of Polyox ${ }^{\mathrm{TM}}$, what we believe happening is that small air bubbles are being suspended in the solution and as the bubble passes through probes, the conductivity changes dramatically and makes very difficult to calculate the residence time of salt slug in the rotor exactly. However, efforts are being made to overcome the above problem and hope to obtain data at higher viscosities.

TABLE 2 . RESIDENCE TIME DATA AT VARIOUS VISCOSITIES

\begin{tabular}{|c|c|c|c|c|c|c|c|}
\hline $\begin{array}{l}\text { Rotor Speed } \\
\text { rpm }\end{array}$ & $\begin{array}{l}\text { Liquid Flow } \\
\text { Rate, gpm }\end{array}$ & $\begin{array}{l}\underline{\operatorname{Ln}(C)} \\
\mathrm{mm}^{*}(\mathrm{gpm})^{2}\end{array}$ & $\begin{array}{l}\text { Residence } \\
\text { Time at lcp }\end{array}$ & \multicolumn{4}{|c|}{$\underline{\text { Residence Time at Viscosity }}$} \\
\hline 600 & 45 & 1401 & & 686 & & & \\
\hline 600 & 60 & 14.59 & 501 & 548 & 617 & 6.49 & \\
\hline 750 & 45 & 14.23 & 5.15 & 588 & & 776 & \\
\hline 750 & 60 & 1481 & 458 & 4.72 & 4.88 & 621 & \\
\hline 750 & 75 & 1526 & 411 & 378 & & 466 & \\
\hline 900 & 30 & 13.60 & 698 & & & & \\
\hline 900 & 45 & 14.42 & 528 & 4.86 & 596 & 6.94 & \\
\hline 900 & 60 & 1499 & 431 & 4.33 & 5.14 & 555 & 591 \\
\hline 900 & 75 & 1544 & & 299 & & 4.34 & 446 \\
\hline 1200 & 30 & 1580 & 623 & & 721 & 779 & \\
\hline 1200 & 45 & 14.70 & & 4.31 & & 5.89 & \\
\hline 1200 & 60 & 1528 & 374 & 380 & 3.80 & 4.30 & \\
\hline 1200 & 75 & 1573 & 2.93 & 328 & & 374 & \\
\hline
\end{tabular}

A total of thirty residence time experiments conducted and summarized in the above Table

2. Electrode tracer response curves pertaining to $8.6 \mathrm{cp}$ and $12 \mathrm{cp}$ are given in appendix $B$ of this report. All the residence time experiments conducted to date at varying viscosities were consolidated and plotted in figure 1 , residence time versus natural logarithm of RPM ${ }^{*} \mathrm{GPM}^{2}$ (liquid flow rate * gas flow rate 2 ) to observe the effects of viscosity on surface tension. 


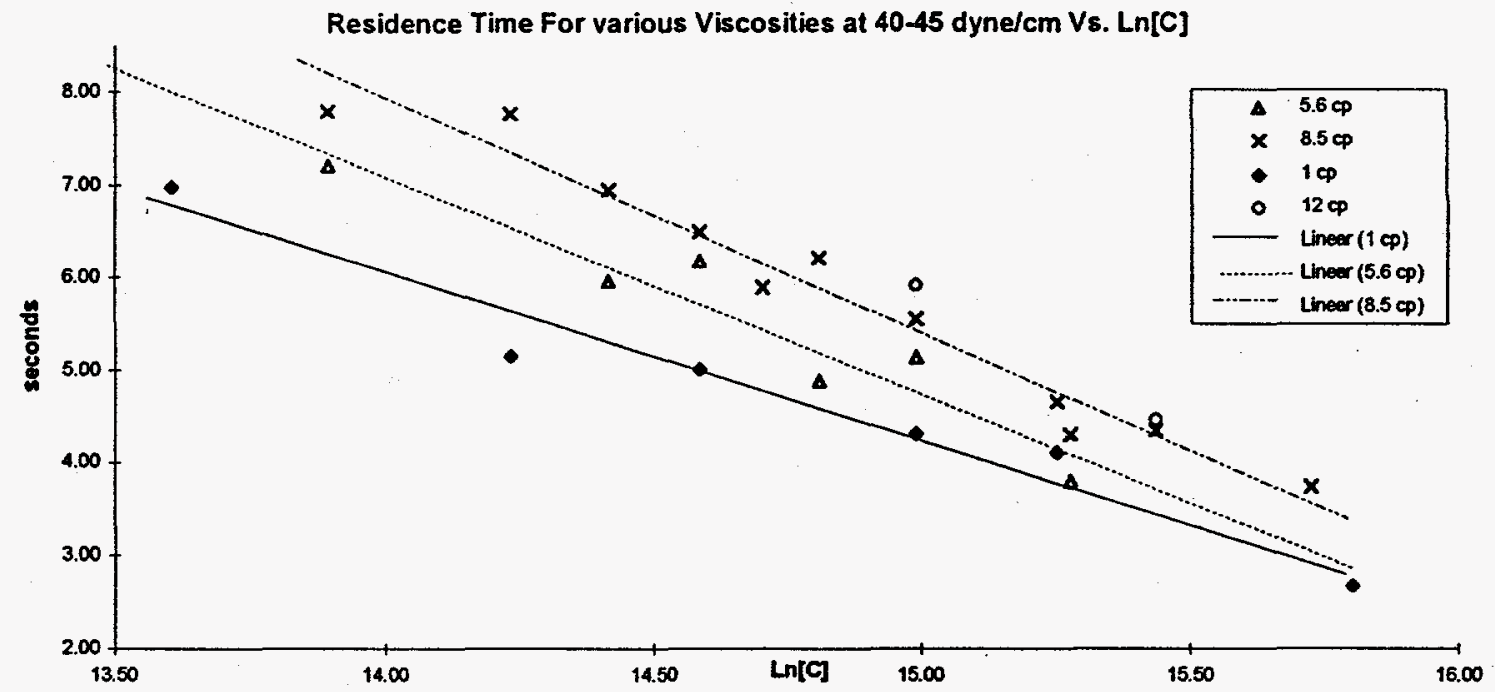

As of date, we have completed all the scheduled viscosity runs in the viscosity range upto 8.5 centipoise. An attempt was also made to run experiments at a higher viscosity in the range of 12-15 $\mathrm{cp}$ and couldn't get reliable data due to high fluid viscosity. The correlation's developed in case of viscosity and surface tension experiments are given in Appendix $C$ of this report.

\section{Task 7. Mass-Transfer Coefficient Studies}

This task was inactive.

\section{Task 8. Field Experimental Studies}

This task was inactive.

\section{Task 9. Data Analysis and Reports}

A poster presentation on this project was made to IGT's Sustaining Membership Program on April 26, 1995 at Sheraton Gateway Suites, Rosemont, IL. A brief presentation on this project was made at GRI during the visit of Saudi Aramco representative on June 5, 1995. During the meeting Saudi Aramco expressed interest in NFM/structured packing technology. Aramco, if it so desires, will contact IGT with respect to developing an NFM/structured packing application in their case. 
Tecnical Progress Report

November 30, 1995

Page 10

IGT Project No. 61103

APPENDIX A

Residence Time Tracer Response curves at $2.8 \mathrm{cp}$ and $5.6 \mathrm{cp}$ 


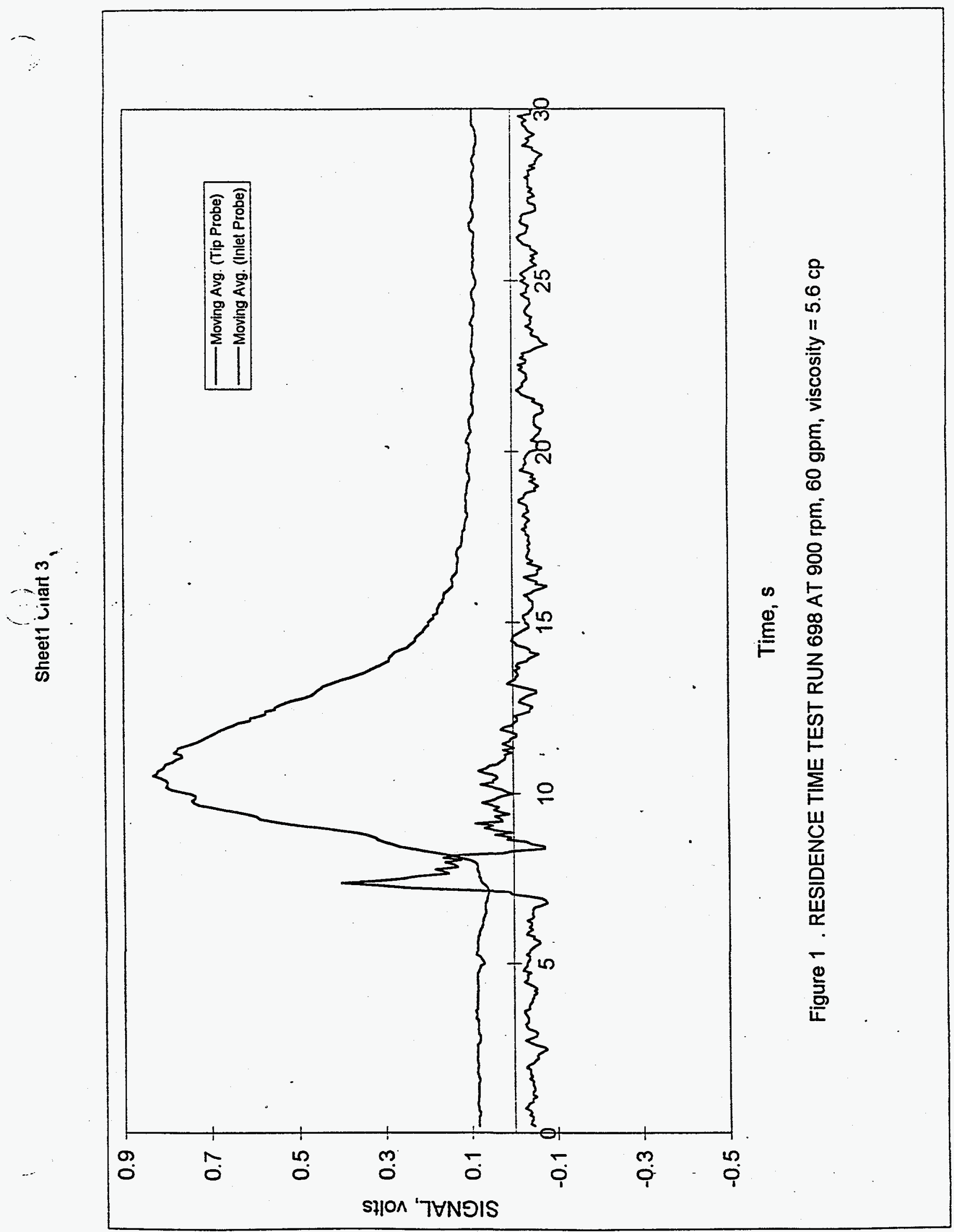




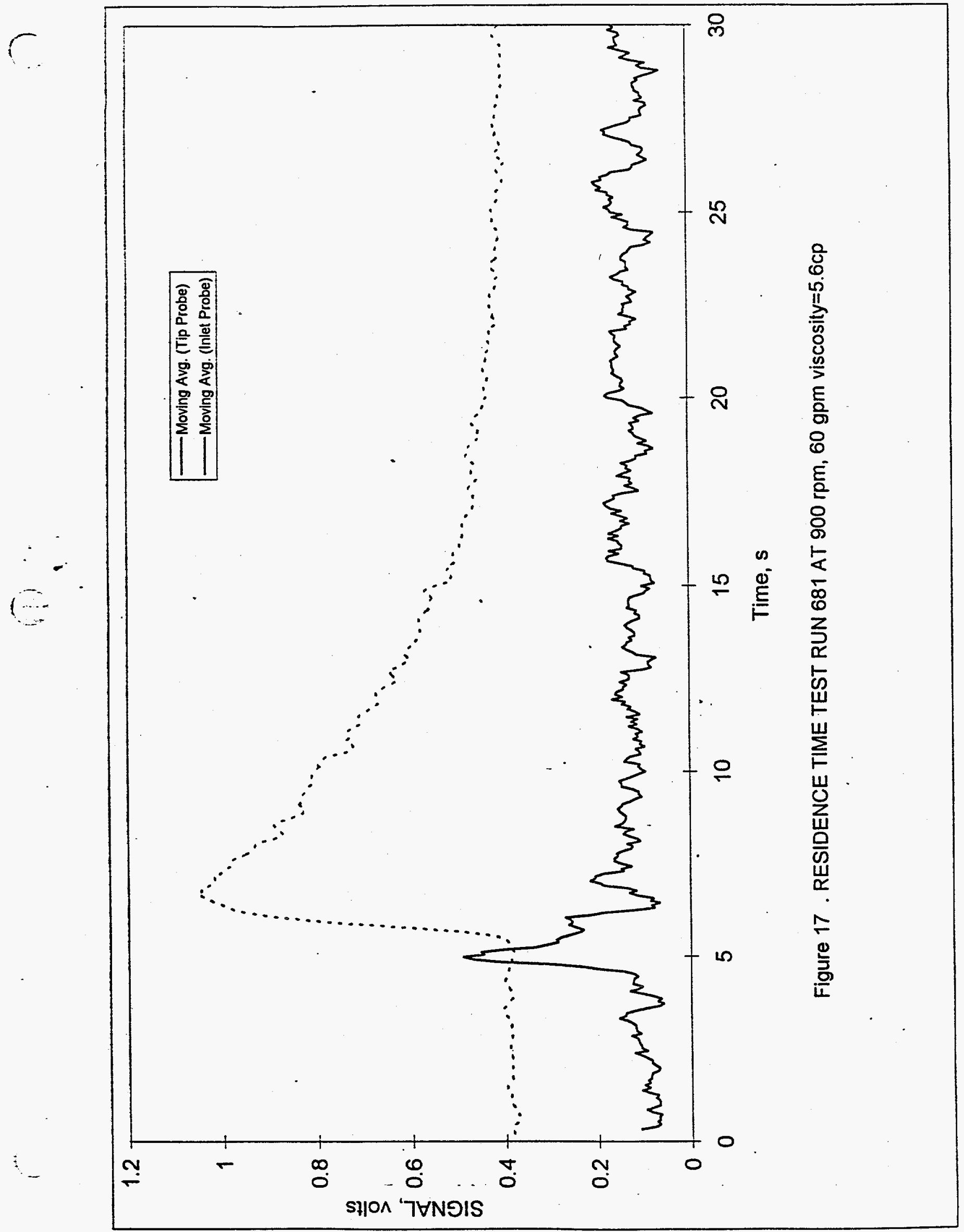




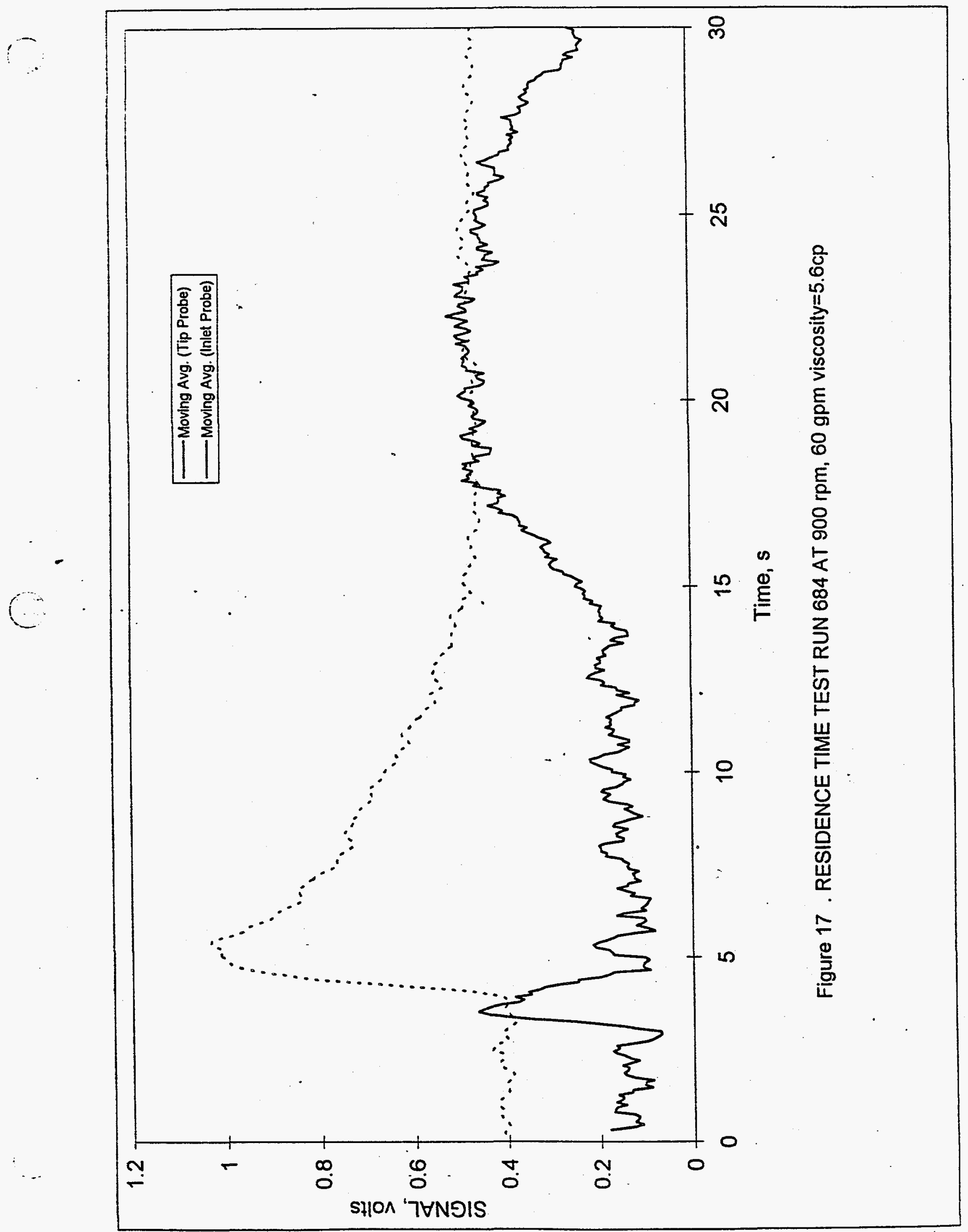




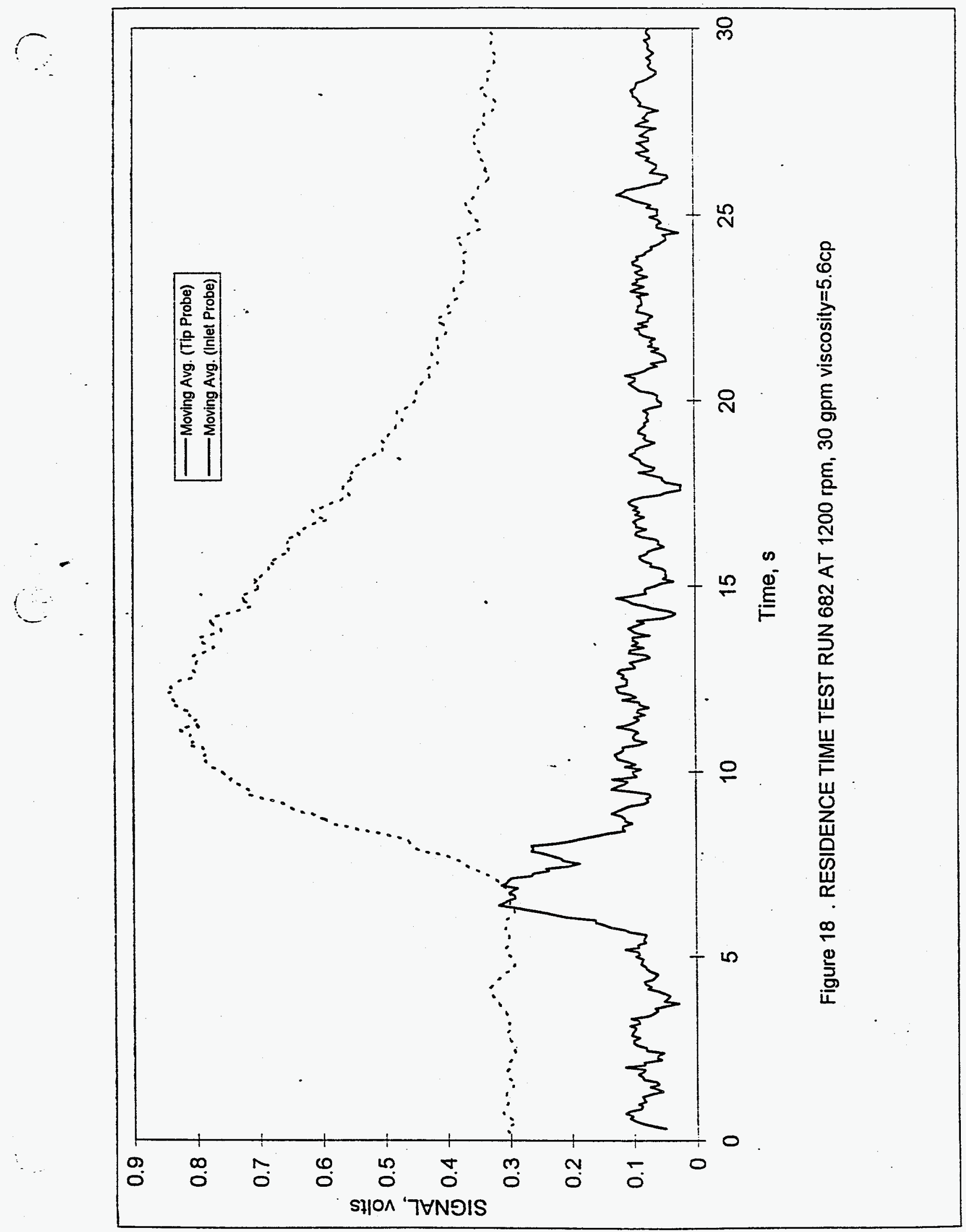




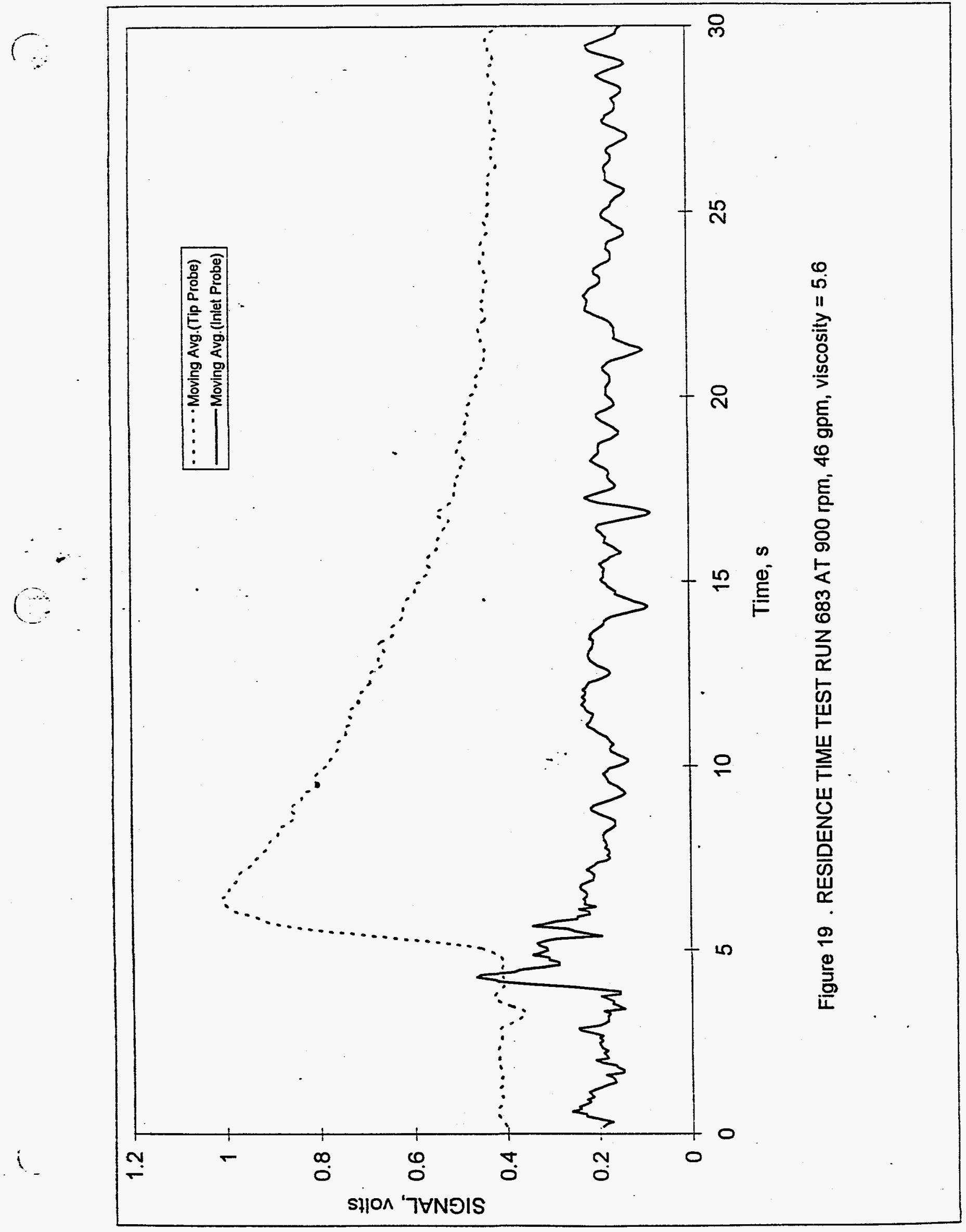




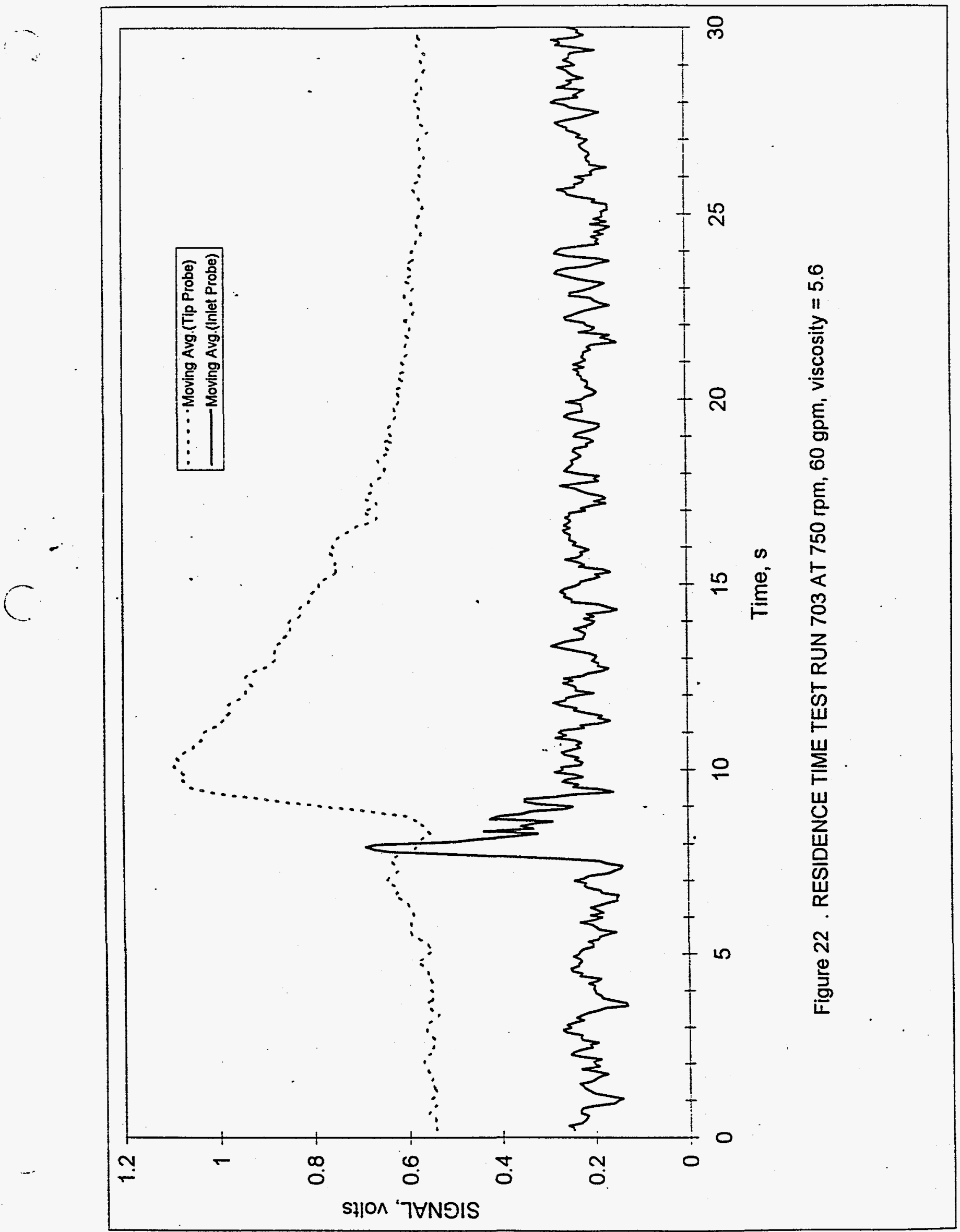




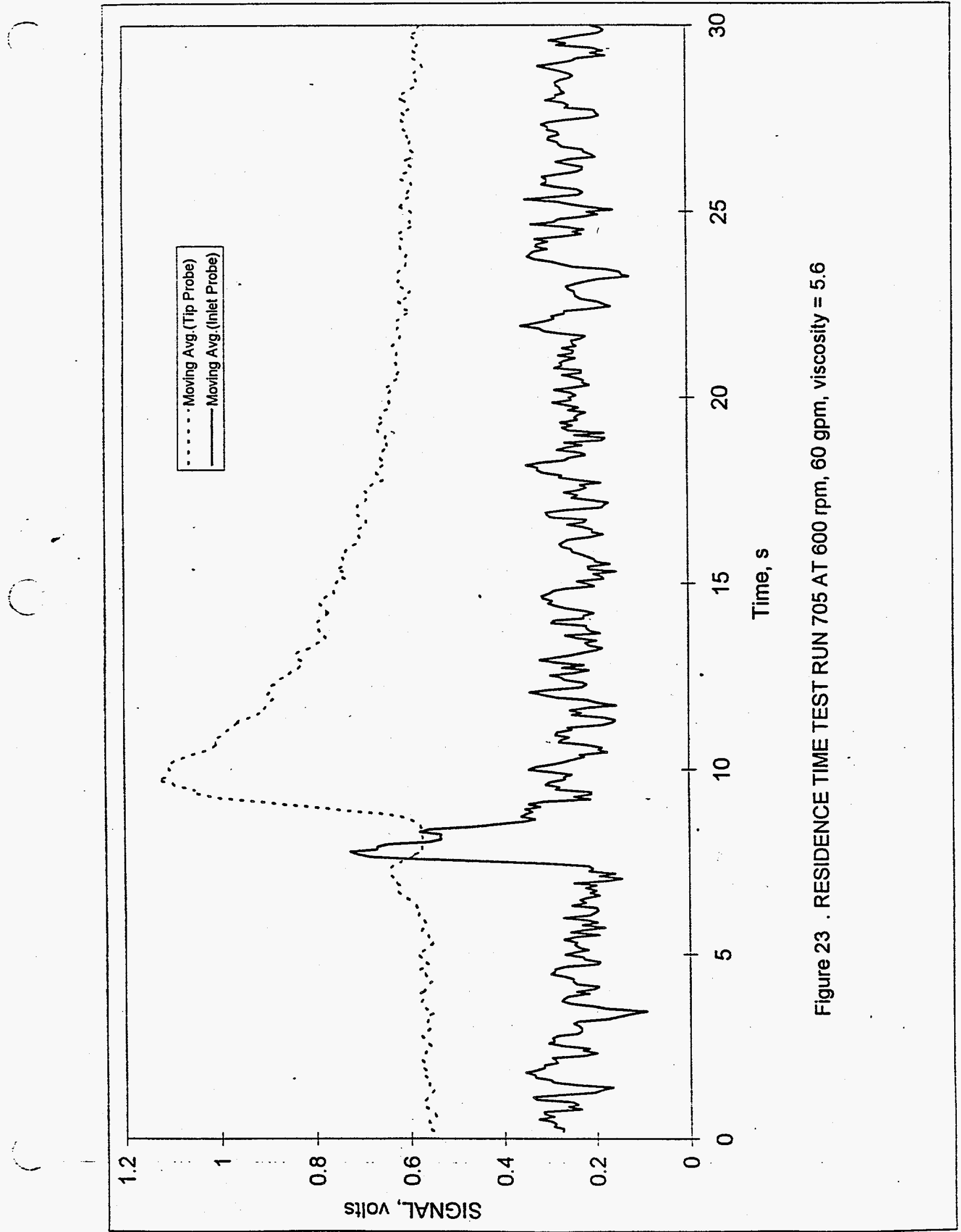




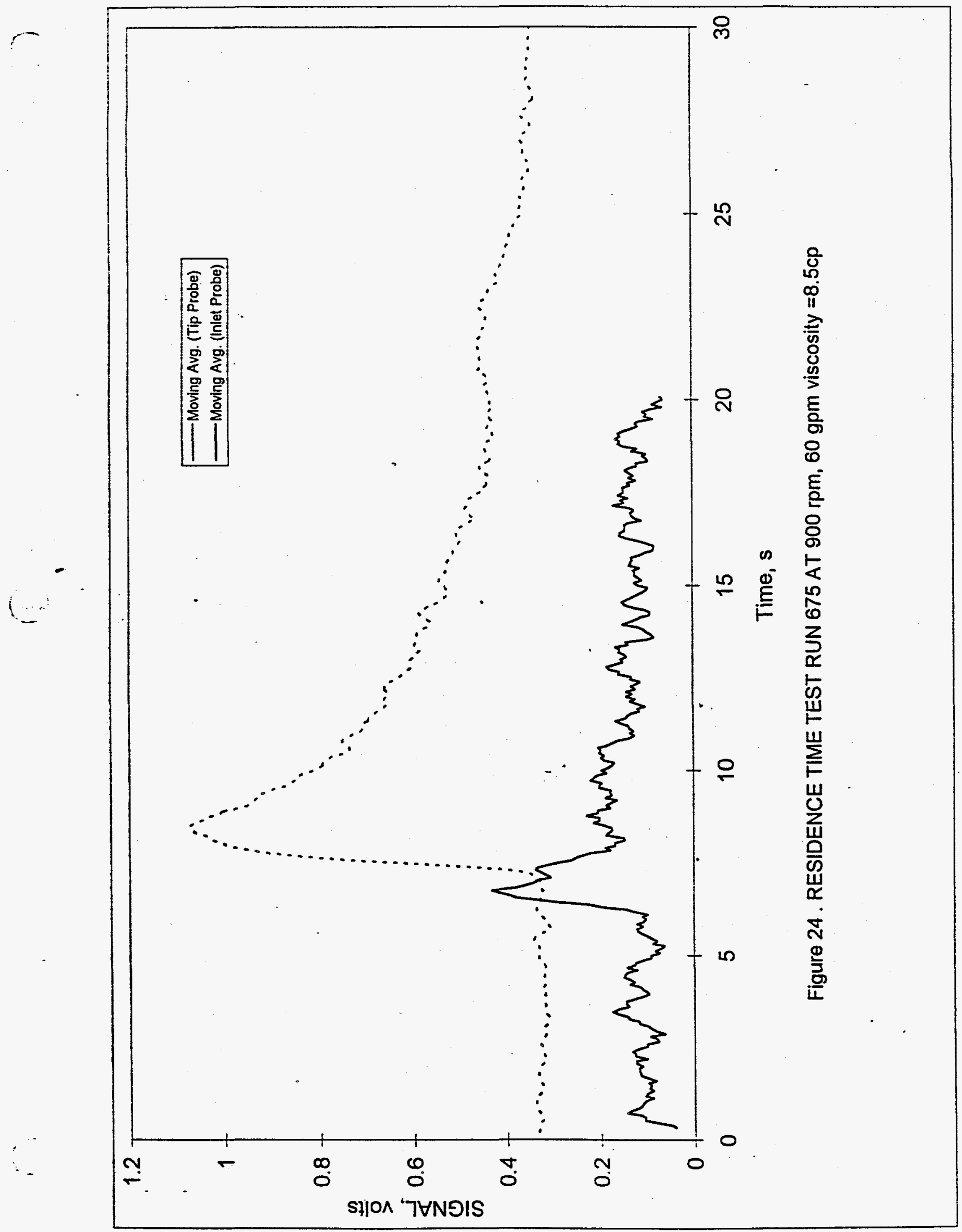




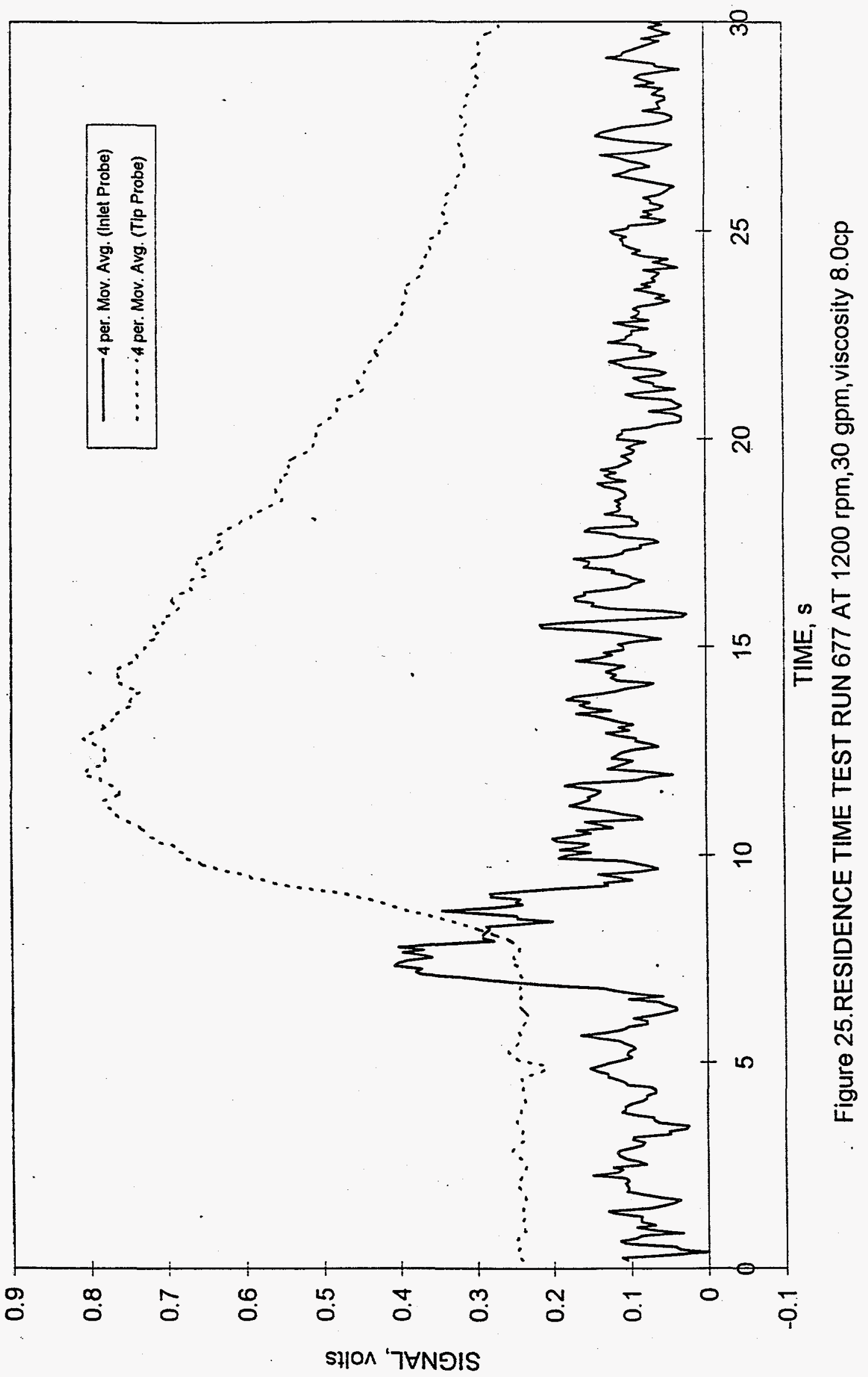


Residence Time vs. $\operatorname{Ln}[\mathrm{C}]$ at Three Surface

Tensions, Experimental and Correlated Results

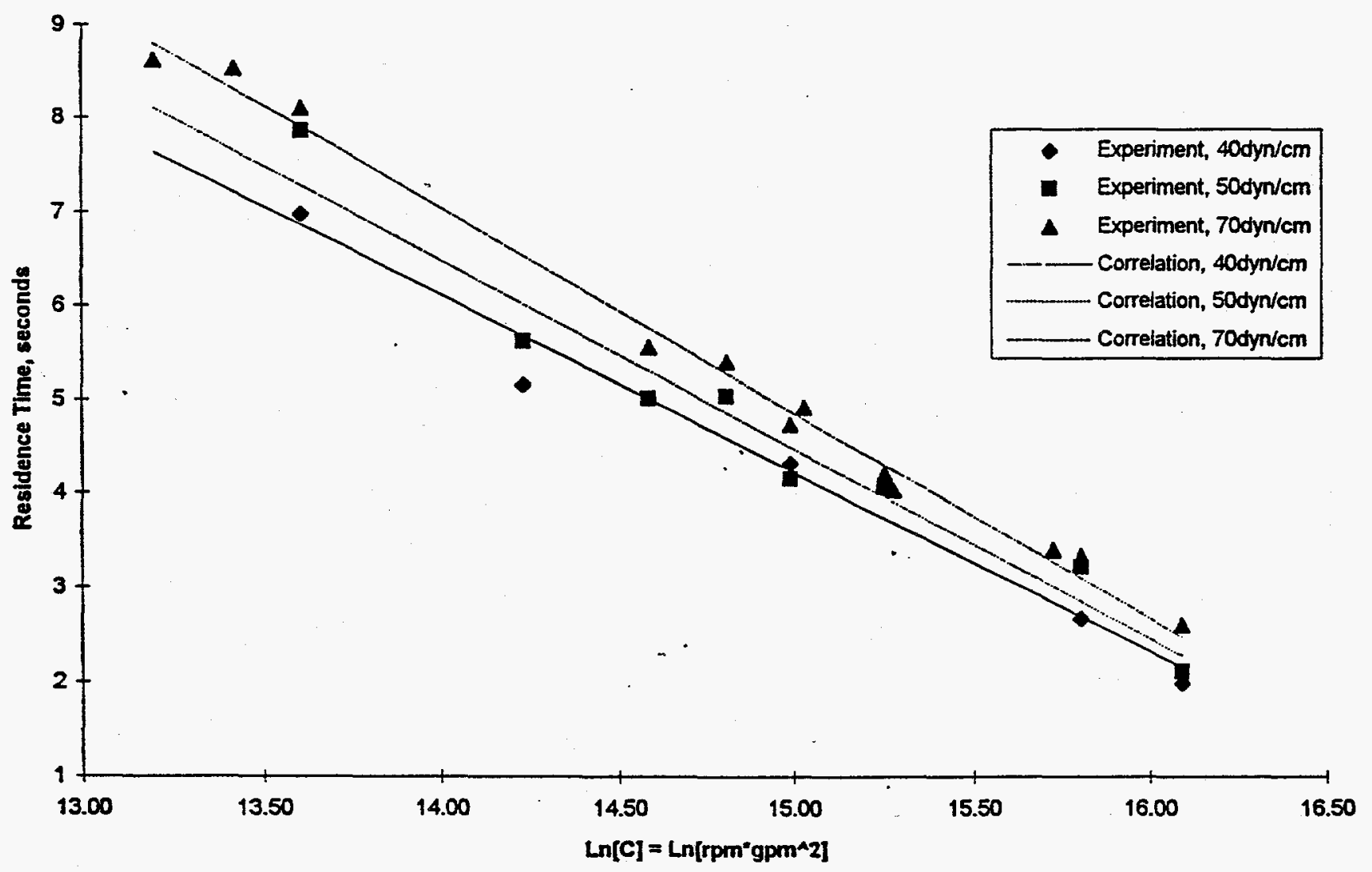


Tecnical Progress Report

November 30, 1995

Page 11

IGT Project No. 61103

APPENDIX B

Residence Time Tracer Response Curves at $8.6 \mathrm{cp}$ and $12.0 \mathrm{cp}$ 


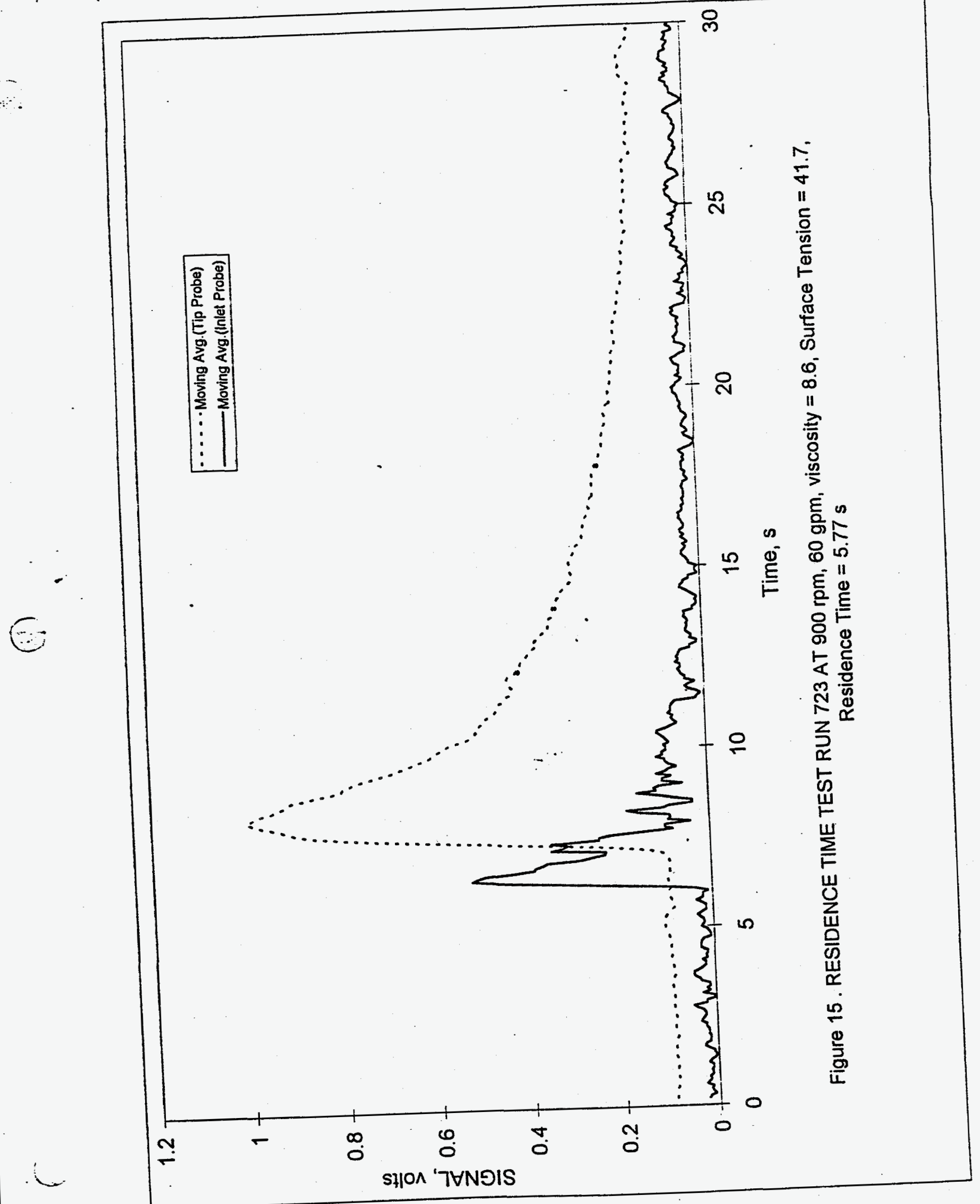




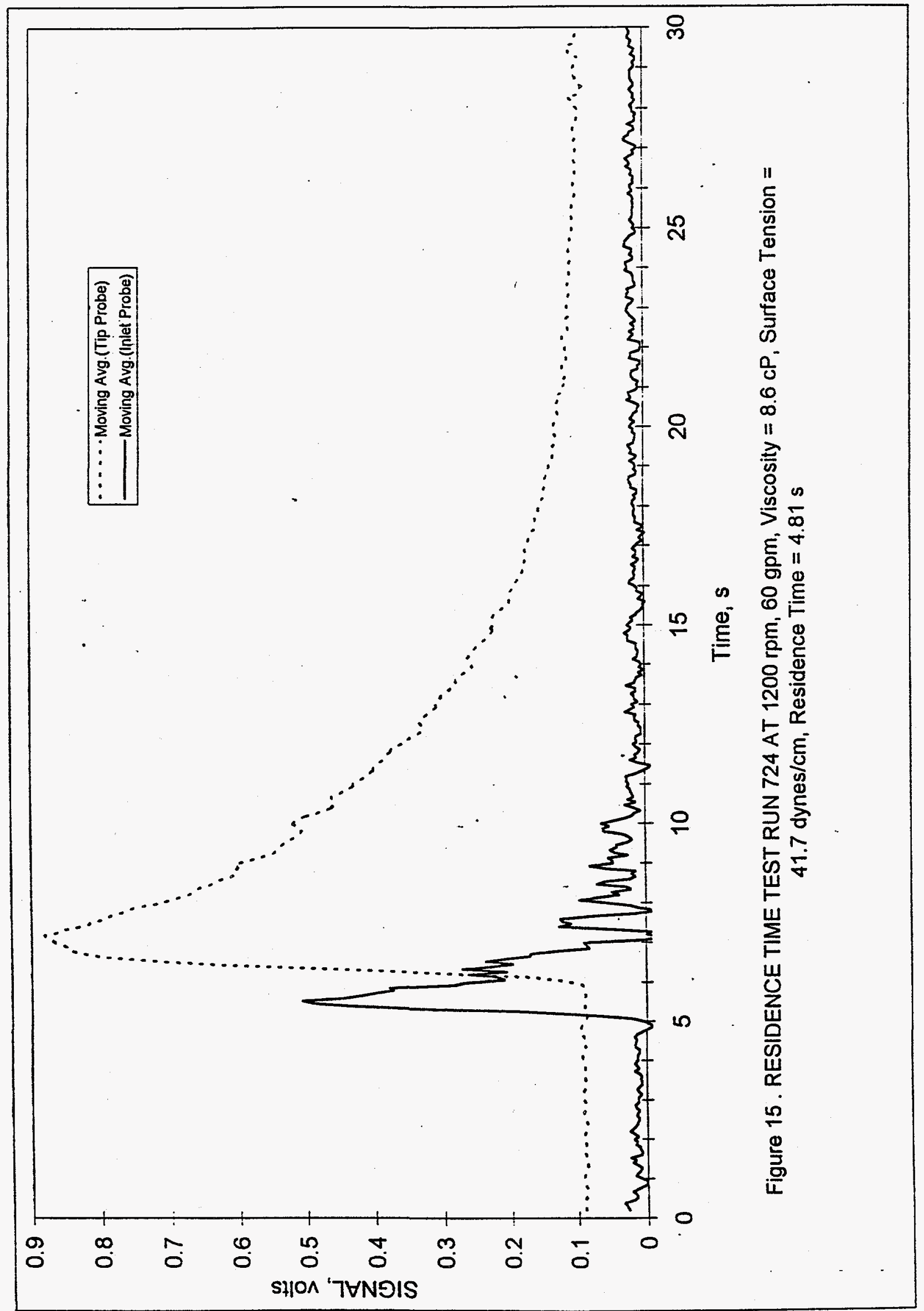




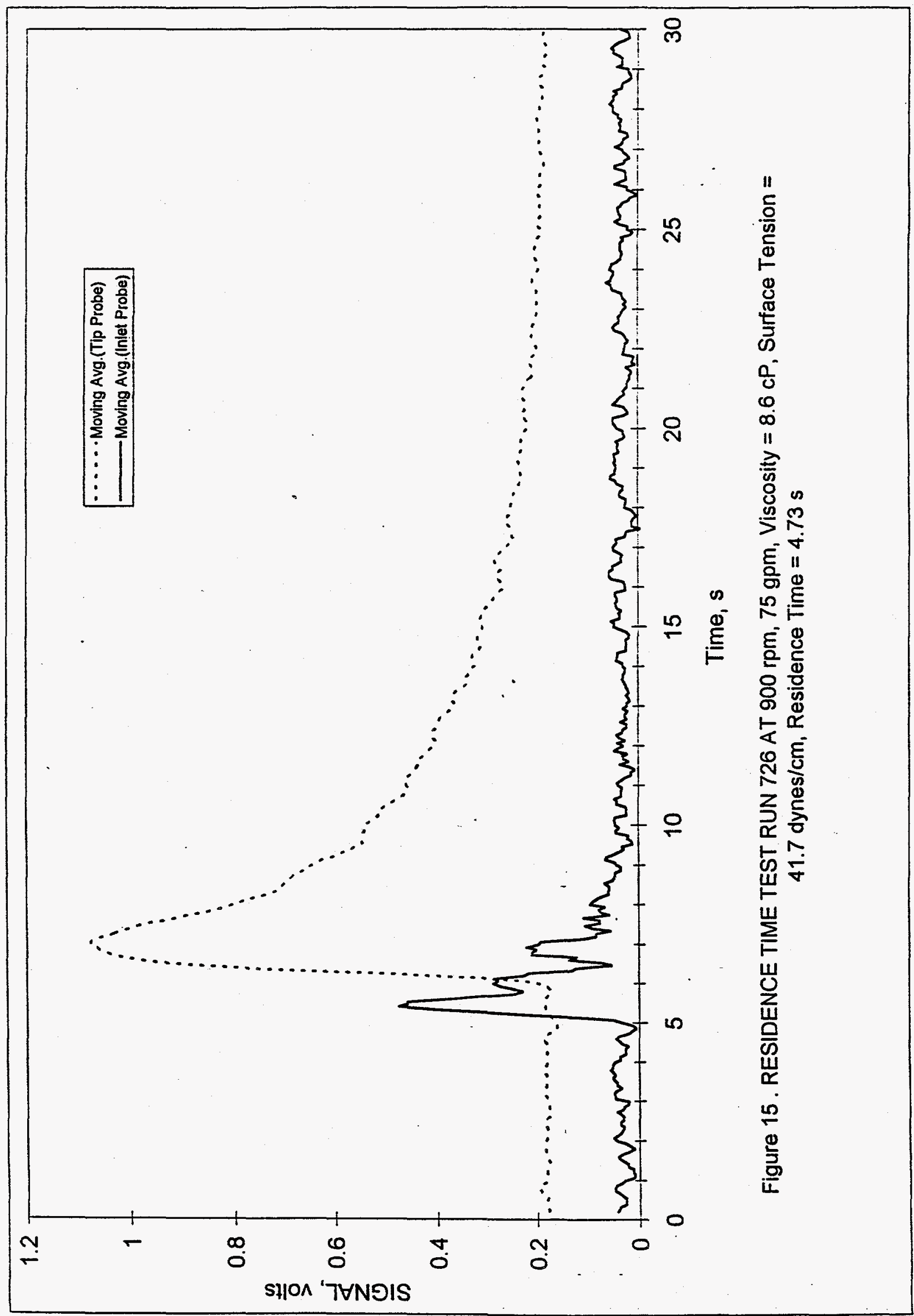




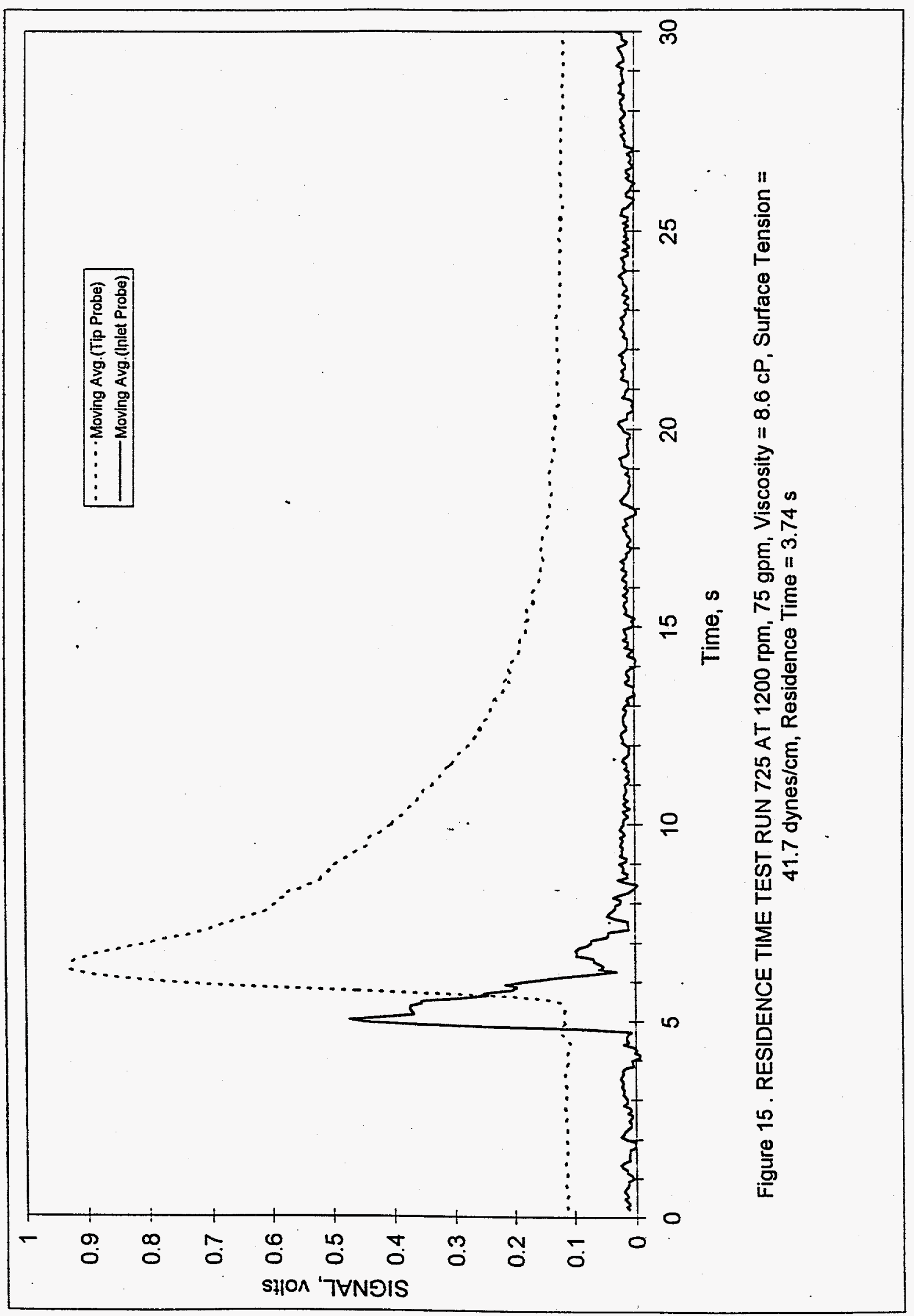




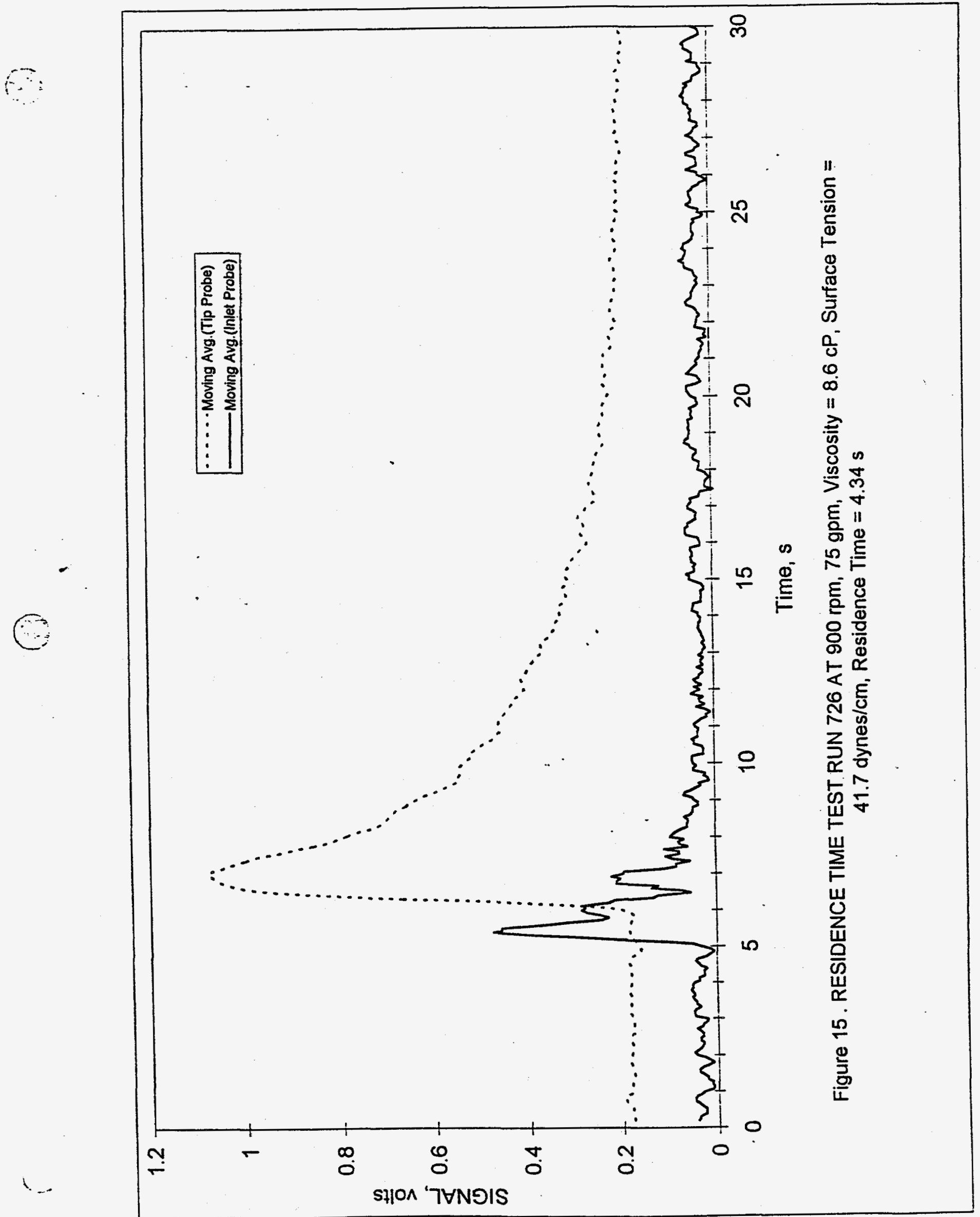




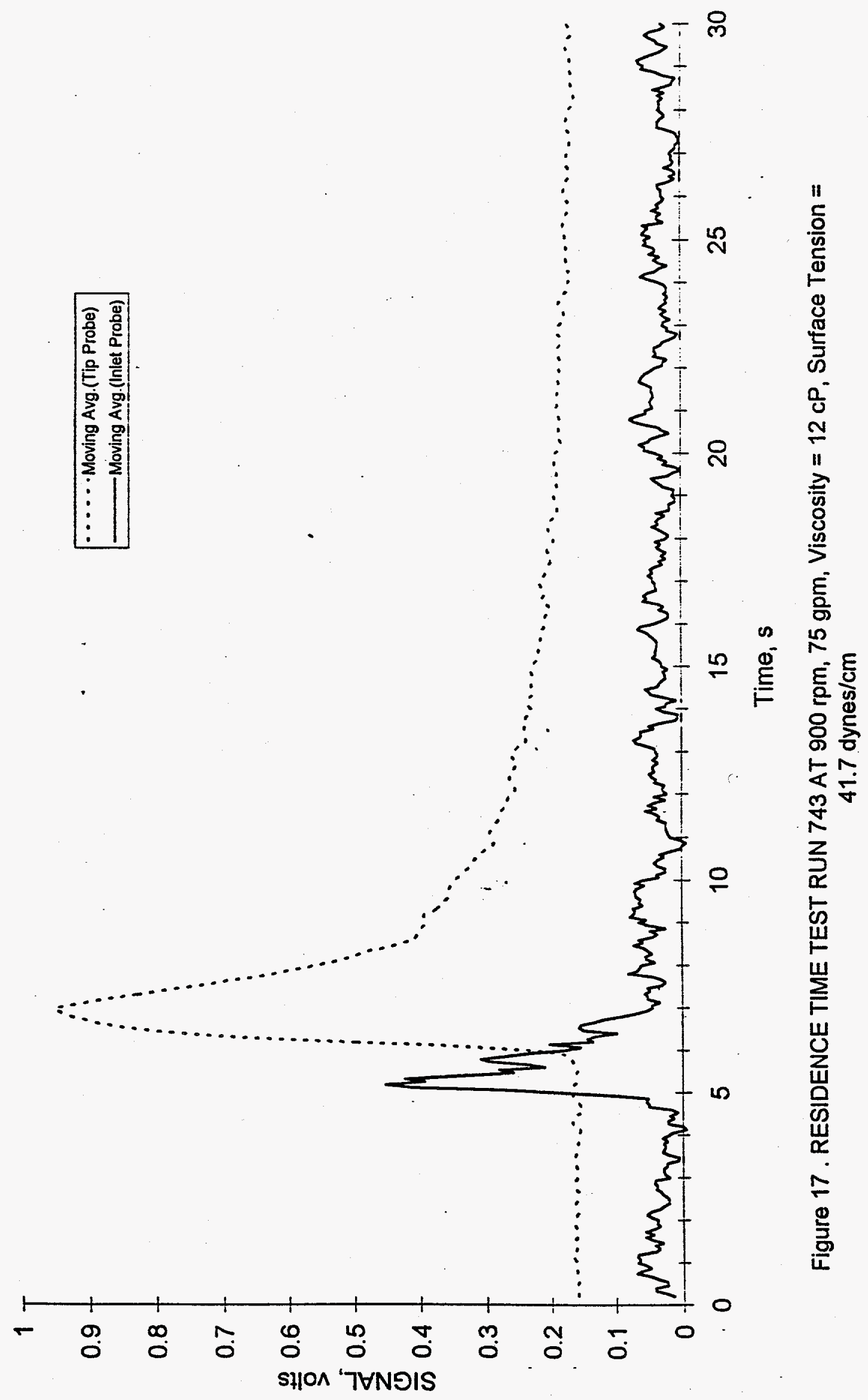




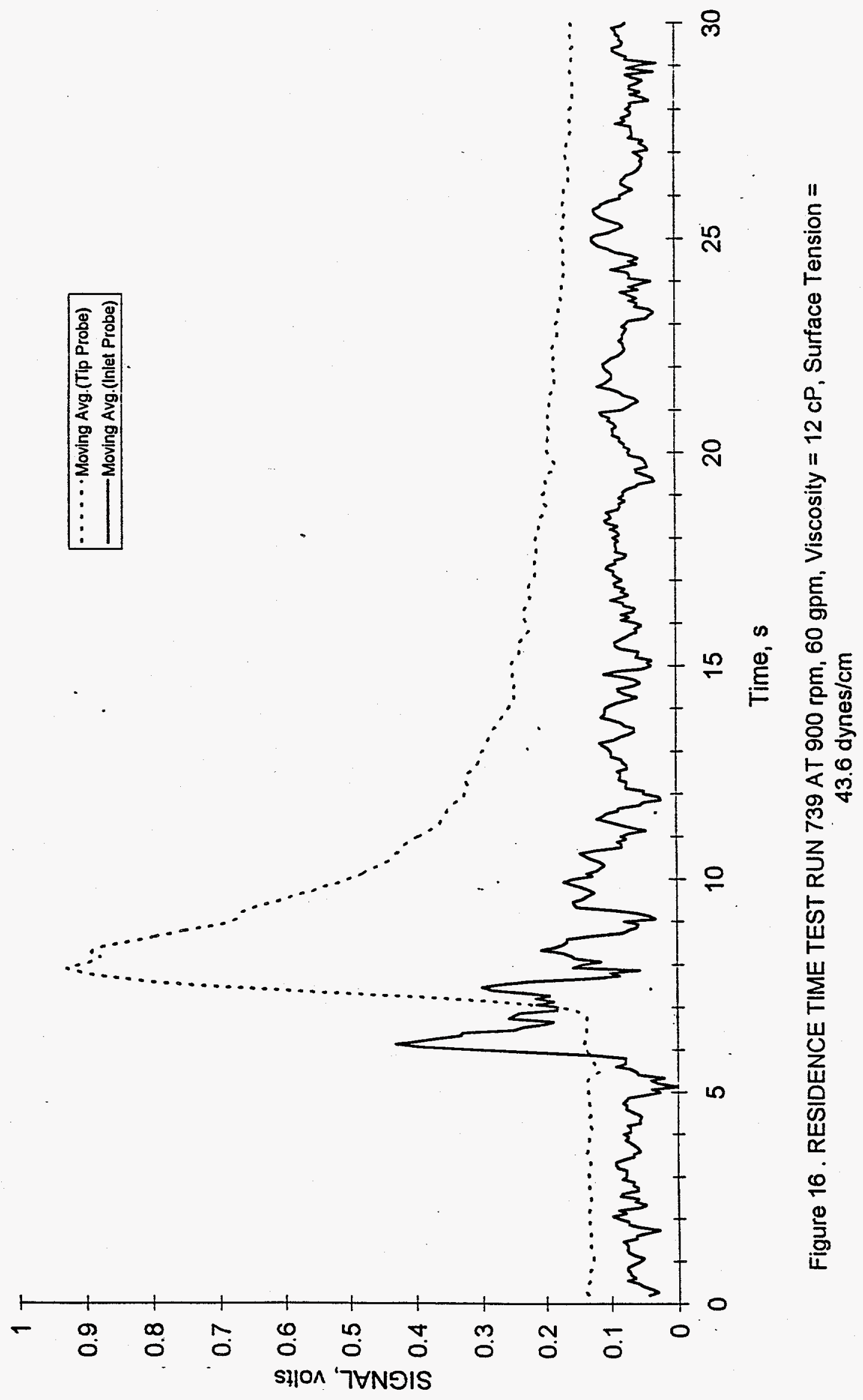




\section{Effect of Surface Tension on Residence Time Correlation}

All the residence time experiments conducted to date at varying surface tensions were consolidated as shown in Table 1 and plotted residence time versus natural logarithm of LPM*GPM $^{2}$ (liquid flow rate * gas flow rate ${ }^{2}$ ) at varying surface tensions to observe the effects of the surface tension on residence time. The data from the 60 dynes $/ \mathrm{cm}$ runs was not used in this correlation due to the few number of data points.

Table 1. Comparison of Residence Time Runs

\begin{tabular}{|c|c|c|c|c|}
\hline & & \multicolumn{3}{|c|}{ Residence Time At } \\
\hline RPM & GPM & 41.9 dynes/cm & 50 dynes/cm & 72 dynes/cm \\
\hline 900 & 60 & 4.306 & 4.416 & 4.53 \\
\hline 900 & 90 & 2.671 & 3.217 & 3.29 \\
\hline 900 & 30 & 6.978 & 7.862 & 8.11 \\
\hline 1200 & 90 & 1.986 & 2.113 & 2.49 \\
\hline 750 & 75 & 4.110 & 3.879 & 4.05 \\
\hline 600 & 60 & 5.012 & 5.006 & 5.41 \\
\hline
\end{tabular}

The initial trends showed three good linear curves for 40,50 , and 70 dynes $/ \mathrm{cm}$. The equations of those curves are respectively,

Res. time $(40$ dynes $/ \mathrm{cm})=-1.8692 * \operatorname{Ln}[\mathrm{C}]+32.233$

Res. time $(50$ dynes $/ \mathrm{cm})=-2.0737^{*} \operatorname{Ln}[\mathrm{C}]+35.575$

Res. time $(70$ dynes $/ \mathrm{cm})=-2.1541^{*} \operatorname{Ln}[\mathrm{C}]+37.199$

With increasing surface tension the slope of these curves becomes greater in magnitude as residence time increases for a given operating condition. To incorporate the effect of surface tension into these trends, we assumed a solution of the form ( $\sigma=$ surface tension):

$$
\text { residence time }=A \operatorname{Ln}[\sigma] \operatorname{Ln}[C]+B \operatorname{Ln}[\sigma]
$$

where $A$ and $B$ are constants. 
By equating the solution to each of the above equations we can solve for three A's:

$$
\begin{aligned}
& A=-1.8692(\operatorname{Ln}(40))^{-1}=-0.5067 \\
& A=-2.0737(\operatorname{Ln}(50))^{-1}=-0.5301 \\
& A=-2.1541(\operatorname{Ln}(70))^{-1}=-0.5070
\end{aligned}
$$

similarly, three B's can be solved for:

$$
\begin{aligned}
& \mathrm{B}=32.233 / \operatorname{Ln} 40=8.74 \\
& \mathrm{~B}=35.575 / \operatorname{Ln} 50=9.09 \\
& \mathrm{~B}=37.199 / \operatorname{Ln} 70=8.76
\end{aligned}
$$

The solutions to both constants vary at most by only $\sim 5 \%$ so it appears that our choice of a general solution is reasonable. By simply finding an average $A$ and $B$ our final equation to correlate operating and surface tension conditions to residence time is:

Residence time $=-0.5146 \operatorname{Ln}[C] \operatorname{Ln}[\sigma]+8.862 \operatorname{Ln}[\sigma]$ 
where $D(v)$ and $E(v)$ are functions of viscosity only. We can easily solve for $a D$ and $E$ at each viscosity tested. If $\mathrm{D}$ and $\mathrm{E}$ are made into second order polynomials of viscosity, then the following constants to the general solution become,

\begin{tabular}{|c|c|c|}
\hline Viscosity & $\underline{\mathbf{D}}$ & $\underline{\mathbf{E}}$ \\
\hline 1 & 0.996 & 0.994 \\
\hline 2.8 & 1.010 & 0.991 \\
\hline 5.6 & 0.994 & 0.910 \\
\hline 8.5 & 1.002 & 0.828 \\
\hline
\end{tabular}

which are in very good agreement with each other. The second order functions for $D$ and $E$ are,

$$
\begin{aligned}
& \mathrm{D}(v)=0.0101 v^{2}-0.1877 v-1.6238 \\
& \mathrm{E}(v)=-0.1406 v^{2}+2.8554 v+28.603
\end{aligned}
$$

Finally, the general correlation becomes,

Res. time $(v)=\left(0.0101 v^{2}-0.1877 v-1.6238\right) \operatorname{Ln}[C]-0.1406 v^{2}+2.8554 v+28.603$ 


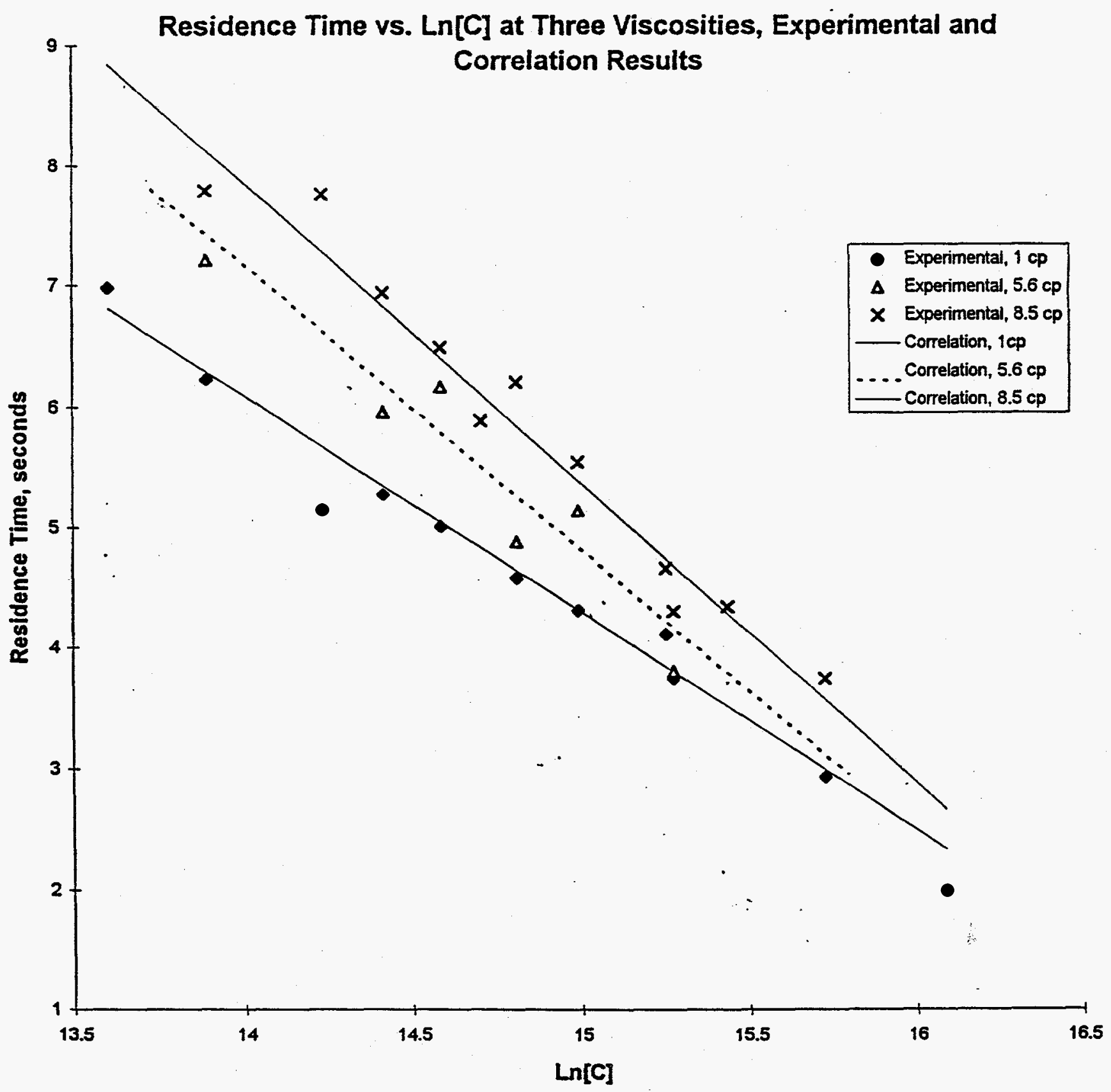


"D" constant vs. Viscosity

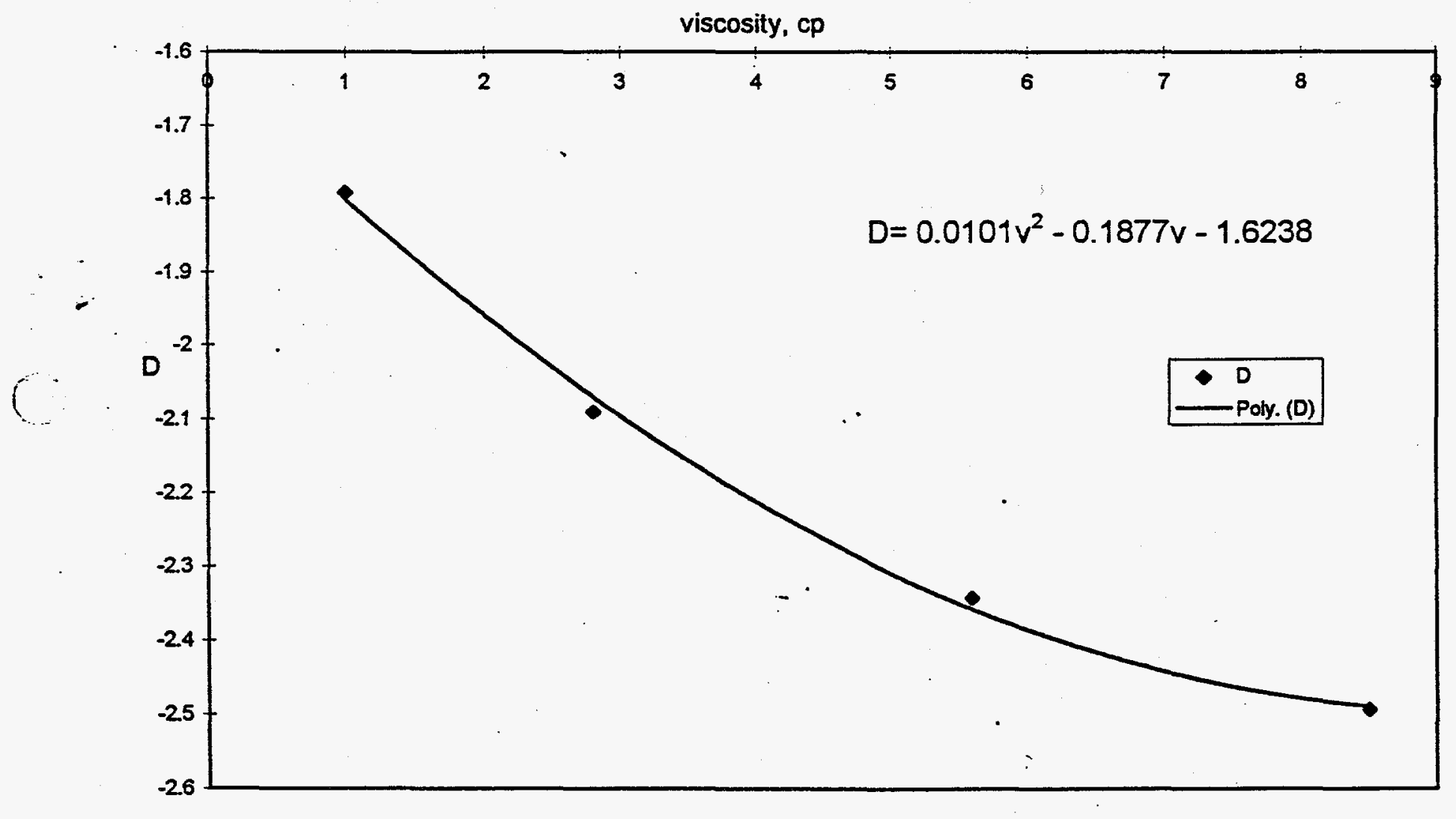




\section{"E" constant vs. Viscosity}

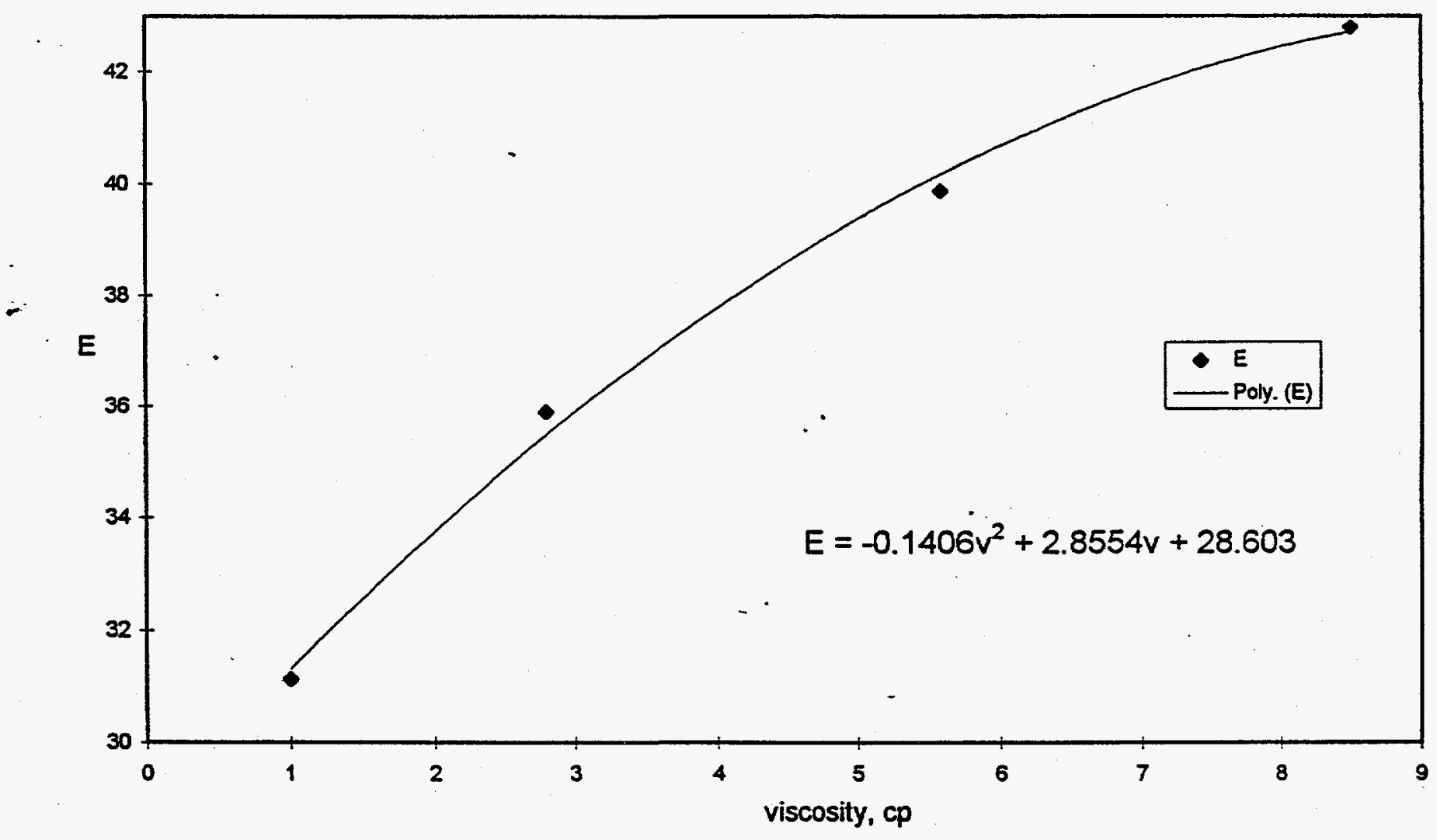

